\title{
Isothermal Heat Measurements of TBP-Nitric Acid Solutions (U)
}

by

J. R. Smith

Westinghouse Savannah River Company

Savannah River Site

Aiken, South Carolina 29808

W. S. Cavin

DOE Contract No. DE-AC09-89SR18035

This paper was prepared in connection with work done under the above contract number with the U.S.

Department of Energy. By acceptance of this paper, the publisher and/or recipient acknowledges the U.S. Government's right to retain a nonexclusive, royalty-free license in and to any copyright covering this paper, along with the right to reproduce and to authorize others to reproduce all or part of the copyrighted paper. 
WSRC-TR-94-0540

Isothermal Heat Measurements of TBP-Nitric Acid Solutions (U)

J.R. Smith and W.S. Cavin

Westinghouse Savannah River Company

Savannah River Site

Aiken, SC 29808

UNCLASSIFIED

DOES NOT CONTAIN

UNCLASSIFIED CONTAOLLED

ADC \&

Roviewing

Official:

NUCLEAR INFORMATION

Dete: 


\section{DISCLAIMER}

This report was prepared as an account of work sponsored by an agency of the United States Government. Neither the United States Government nor any agency thereof, nor any of their employees, makes any warranty, express or implied, or assumes any legal liability or responsibility for the accuracy, completeness, or usefulness of any information, apparatus, product, or process disclosed, or represents that its use would not infringe privately owned rights. Reference herein to any specific commercial product, process, or service by trade name, trademark, manufacturer, or otherwise does not necessarily constitute or imply its endorsement, recommendation, or favoring by the United States Government or any agency thereof. The views and opinions of authors expressed herein do not necessarily state or reflect those of the United States Government or any agency thereof.

This report has been reproduced directly from the best available copy.

Available to DOE and DOE contractors from the Office of Scientific and Technical Information, P.O. Box 62, Oak Ridge, TN 37831; prices available from (615) 576-8401.

Available to the public from the National Technical Information Service, U.S. Department of Commerce, 5285 Port Royal Road, Springfield, VA 22161. 


\section{DISCLAIMER}

Portions of this document may be illegible in electronic image products. Images are produced from the best available original document. 
WSRC-TR-94-0540

$\mathrm{Pg} 1$ of 45

Isothermal Heat Measurements of TBP-Nitric Acid Solutions (U)
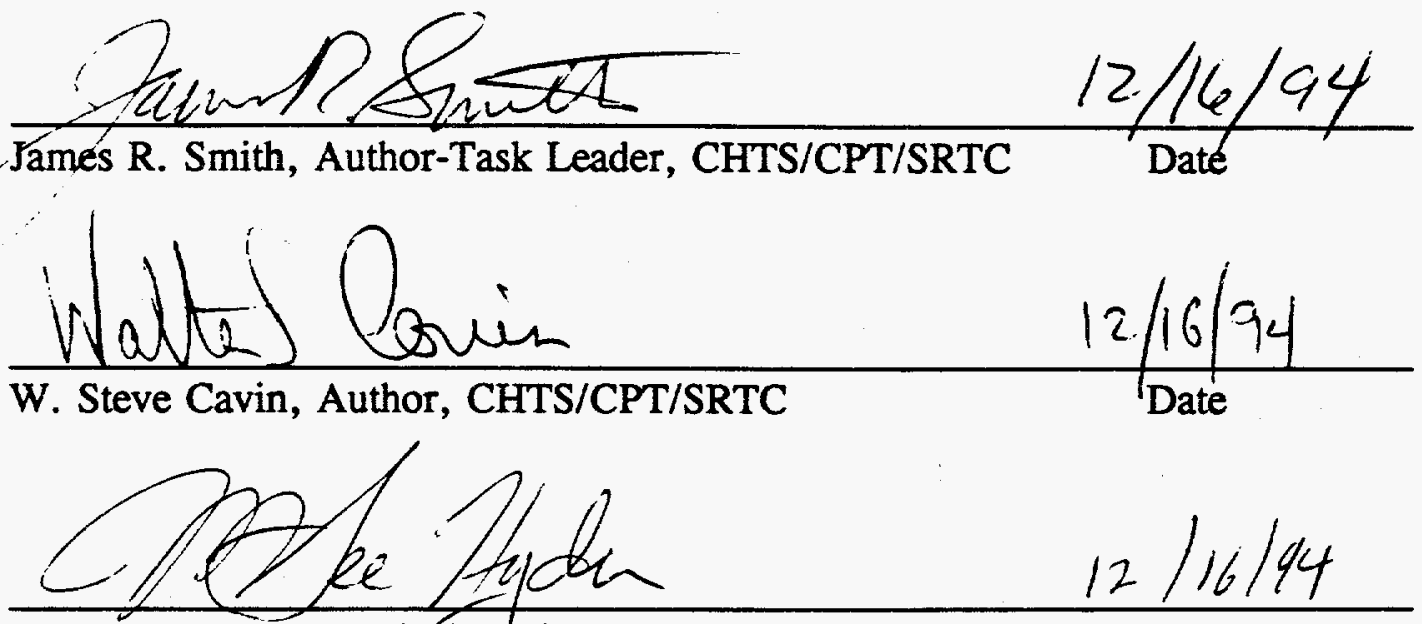

M. Lee Hyder, Technical Reviewer, CHTS/CPT/SRTC

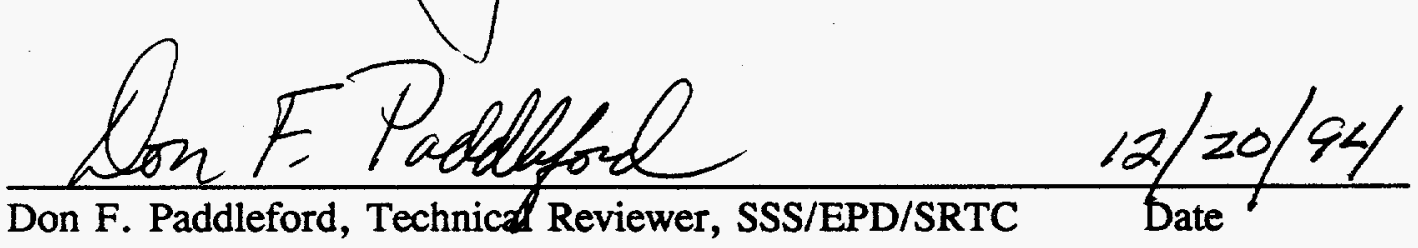

December 16, 1994

Westinghouse Savannah River Company Savannah River Site Aiken, SC 29808 


\section{CONTENTS}

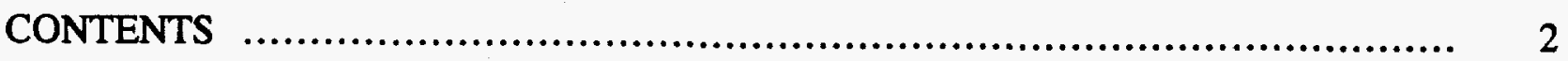

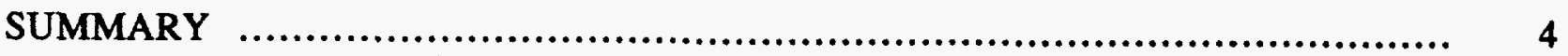

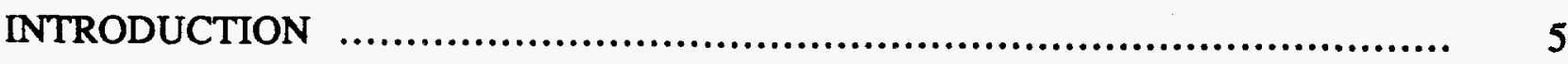

EXPERIMENTAL ....................................................................... 5

Isothermal Calorimeter ................................................................... 5

Heat-Balance Calorimeter .......................................................... 7

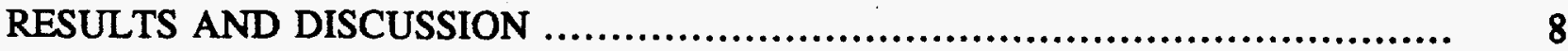

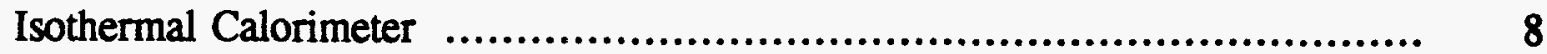

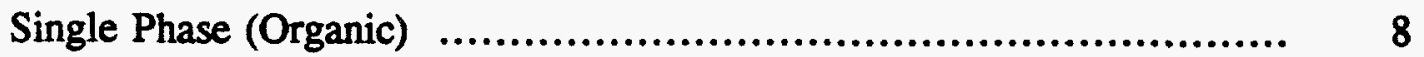

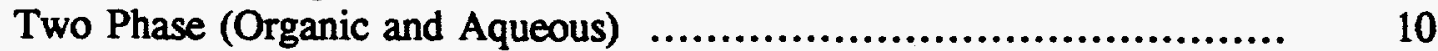

Heat-Balance Calorimeter .............................................................. 15

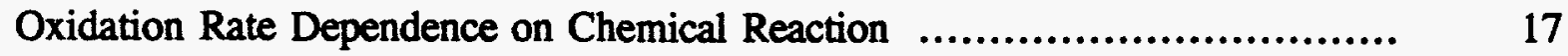

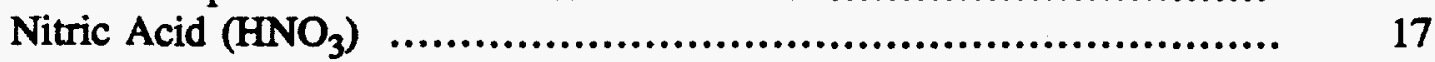

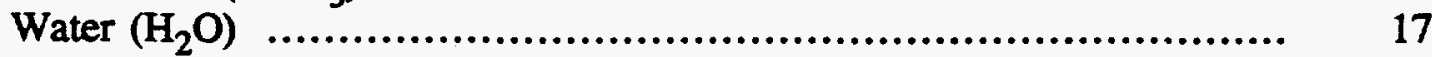

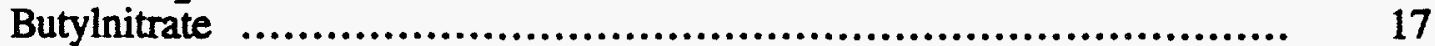

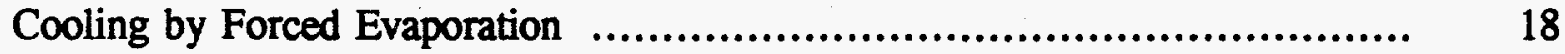

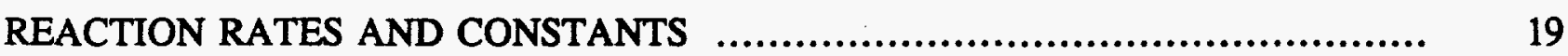

Single Phase (Organic) ............................................................ 19

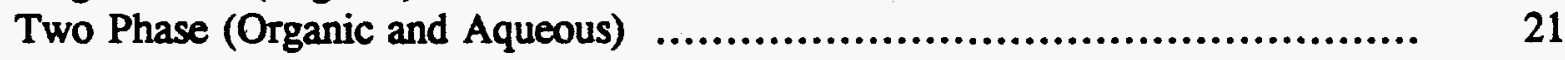

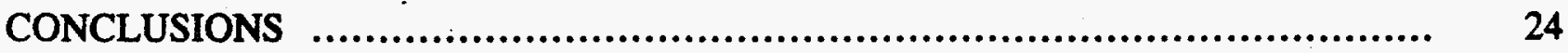

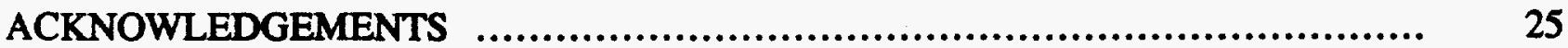

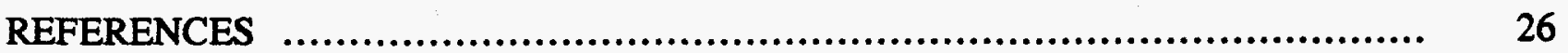

TABLES

Table 1 - Calorimetry Runs (Experiments) Conditions ......................... 9

Table 2 - Run \#3 - Mass, Charge, and Heat Balance. Reaction Stoichiometry .. 11

Table 3 - Run \#5 - Mass, Charge, and Heat Balance. Reaction Stoichiometry .. $\quad 12$

Table 4 - Run \#11 - Mass, Charge, and Heat Balance. Reaction Stoichiometry 13 
WSRC-TR-94-0540

$\operatorname{Pg} 3$ of 45

TABLES (continued)

Table 5 - Run \#13 - Mass, Charge, and Heat Balance. Reaction Stoichiometry 14

Table 6 - Reaction Stoichiometries and Heats Per Measurable Quantity ........ 16

Table 7 - Maximum Organic to Aqueous Thickness Ratio ....................... 23

FIGURES

Figure 1 - Isothermal (Peltier) Calorimeter ..................................... 27

Figure 2 - Isothermal Calorimeter Calibration ................................... 28

Figure 3 - Heat-Balance Calorimeter ............................................. 39

Figure 4 - Heat-Balance Calorimeter Calibration ............................... 30

Figure 5 - Heat Output Versus Time, TBP $\left(10 \mathrm{M} \mathrm{HNO}_{3}\right)$ at $110^{\circ} \mathrm{C} \ldots \ldots \ldots \ldots . . .31$

Figure 6 - Heat Output Versus Time, TBP $\left(10 \mathrm{M} \mathrm{HNO}_{3}\right)$ at $124^{\circ} \mathrm{C} \ldots \ldots \ldots \ldots . .32$

Figure 7 - Off-Gas Rate Versus Time for Single Phase Runs ................... 33

Figure 8 - Oxidation Rate Dependence on $\left[\mathrm{HNO}_{3}\right]$ (organic phase) ............. 34

Figure 9 - Condensation Rate Versus Time at $124^{\circ} \mathrm{C}$........................... 35

Figure 10 - Two-Phase Reaction Characteristics, 110 and $10 \mathrm{M}\left[\mathrm{HNO}_{3}\right] \ldots \ldots . . \quad 36$

Figure 11 - Run \#15 - 4 Inches Aqueous and 5 Inches Organic Phase .......... 37

Figure 12 - Run $\# 16$ - 4 Inches Aqueous and 8 Inches Organic Phase ........... 38

Figure 13 - Organic/Aqueous Thickness Ratio Versus Total Off-Gas Rate ....... 39

Figure 14 - Effect of First Order Dependence on [Butylnitrate] ................... 40

Figure 15 - Mole Ratio Condensate to Off-Gas Versus Temperature ............. 41

Figure 16 - Net Cooling Rate Relative to Boiling Point ......................... 42

Figure 17 - Model Fit to Single Layer $\left(110^{\circ} \mathrm{C}\right)$ Experimental Data .............. 43

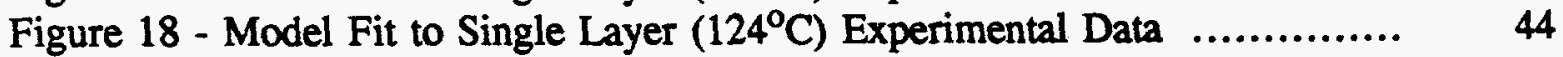

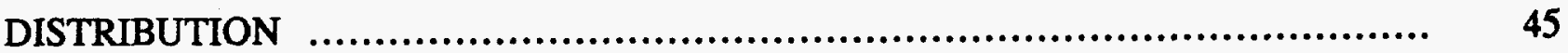


WSRC-TR-94-0540

$\mathrm{Pg} 4$ of 45

Isothermal Heat Measurement of TBP-Nitric Acid Solutions (U)

\author{
by J. R. Smith and W. S. Cavin \\ Westinghouse Savannah River Company \\ Savannah River Site \\ Aiken, SC 29808
}

\title{
SUMMARY
}

Net heats of reaction were measured in an isothermal calorimeter for both single phase (organic) and two phase (organic and aqueous) $\mathrm{TBP} / \mathrm{HNO}_{3}$ reacting solutions at temperatures above $100^{\circ} \mathrm{C}$. The oxidation rate constant was determined to be $5.4 \mathrm{E}-4 \mathrm{~min}^{-1}$ at $110^{\circ} \mathrm{C}$ for an open "vented" system as compared to $1.33 \mathrm{E}-3 \mathrm{~min}^{-1}$ in the closed system. The heat released per unit material oxidized was also reduced. The oxidation in both phases was found to be first order in nitric acid and pseudo-zero order in butylnitrate and water. The hydrolysis (esterfication) rate constant determined by Nichols' $\left(1.33 \mathrm{E}-3 \mathrm{~min}^{-1}\right)$ fit the experimental data from this work well. Forced evaporation of the volatile components by the product gases from oxidaton resulted in a cooling mechanism which more than balanced the heat from the oxidation reaction in the two-phased systems. Water, the main coolant in the organic phase, was maintained by interfacial mixing by gas produced from oxidation in the aqueous phase.

Rate expressions were derived and rate constants determined for both the single and two phase systems. An approximating mathematical model was developed to fit the experimental data and to extrapolate beyond the experimental conditions. This model shows that one foot of "reacting" $14.3 \mathrm{M} \mathrm{HNO}_{3}$ aqueous phase solution at $121^{\circ} \mathrm{C}$ will transport sufficient water to the organic phase to replace evaporative losses, maintaining endothermicity, for organic layers up to $12.2 \pm 6.0$ feet deep. If the pressure in a reacting system is allowed to increase due to insufficient venting the temperature of the organic phase would increase in temperature to reach a new equilibrium. The rate of oxidation would increase not only due to the increase in temperature but also from the increased concentration of dissolved $\mathrm{HNO}_{3}$ reduction products. Another important factor is that the cooling system described in this work becomes less effective as the total pressure increases. These factors probably contributed to the explosion at Tomsk. 
WSRC-TR-94-0540

$\mathrm{Pg} 5$ of 45

\section{INTRODUCTION}

An explosion in a separations facility in Tomsk, Russia, has raised questions about the safety of similar DOE facilities. These safety concerns led to research to determine the boundary conditions for safe operation of evaporators and tanks that contain both TBP (tributylphosphate) and $\mathrm{HNO}_{3}$ (nitric acid). The present work focuses on determining the heat balance (heat produced minus the heat lost from evaporation) of a $\mathrm{TBP} / \mathrm{HNO}_{3}$ solution of a given geometry and size at elevated temperatures.

Experimental data has been acquired using an isothermal calorimeter ${ }^{1}$ and a heat balance calorimeter. This data has enabled the calculation of the Net Heat produced per unit volume of reacting solution versus time for varying conditions. Analysis of the resulting solutions, condensates, and off-gas products has allowed mass, charge, and electron balances and the determination of the overall reaction stoichiometries. A subtask, led by J.E. Laurinat, determined the dispersion coefficients for gas bubbling transfer of water and butanol between the two phases ${ }^{2}$.

Rate expressions were derived for the reacting systems and then fit to the data to determine the rate constants for the various physical processes affecting the Net Heat of the reacting solutions. These expressions and constants were then used to extrapolate beyond the experimental conditions.

\section{EXPERIMENTAL}

\section{Isothermal Calorimeter}

A simple isothermal calorimeter was designed, Figure 1, and constructed to determine the net heat production rate from the reaction of TBP and nitric acid solution mixtures (including two-phase systems) up to $125^{\circ} \mathrm{C}$. The calorimeter was designed to contain up to a total of 100 $\mathrm{ml}$ of solution. Estimates had predicted a net heat production rate of between 0.1 and about 5 watts for a temperature range of 80 to $125^{\circ} \mathrm{C}$. Early calibrations had determined the sensitivity to be about \pm 0.2 watts for $50 \mathrm{ml}$ of solution in this heat output range $\mathrm{e}^{3}$. At $110^{\circ} \mathrm{C}$ the heat production rate was expected to be about 2.5 watts giving a precision of $< \pm 10 \%$. The calorimeter was constructed in a cylindrical geometry allowing change of the reaction solution volume without changing the surface area for evaporation. This was expected to enable separation of the heat production and heat loss components.

The isothermal calorimeter was calibrated by balancing the heat input of a precision resistor with a Peltier device. The heat pumped out of (or added to) the solution in the reaction chamber is proportional to the current flowing through the Peltier. The power was added to the resistance heater by a Kepco DC Power Supply (T-20606, S.N. E42110). The voltage and current supplied to the resistor were measured by two Fluke multimeters (M\&TE\# WFQ-1306 and EA-131 respectively). The current delivered to the Peltier by a Kepco DC Power Supply 
WSRC-TR-94-0540

$\mathrm{Pg} 6$ of 45

(T-0023310), was measured by another Fluke multimeter (M\&TE EAQ-1857). The dates that these M\&TE devices were used to acquire data was logged and are being kept as records along with the calibration records for each multimeter. A calibration was performed for the various experimental conditions (reaction solution volume and temperature) with pure TBP in the calorimeter reaction chamber. These calibrations were also performed intermittently during the 13 experimental runs in the isothermal calorimeter. The calibrations results, Figure 2, show that the heat removal by the Peltier was independent of the temperature and volume of the TBP solution. The heat removed is linear and proportional to 0.220 watts per amp of current delivered to the Peltier. Reversing the direction of the DC current causes the Peltier to pump heat into the reaction solution as opposed to pumping heat out.

The calorimeter main housing was preheated to the desired temperature of reaction (either 110 or $125^{\circ} \mathrm{C}$ ) prior to addition of the reaction solutions. The organic phase was presaturated with a known concentration of aqueous solution (such as $10 \mathrm{M} \mathrm{HNO}$ solution) by shaking a five volumes of the aqueous phase with one volume of reagent grade TBP. A measured volume of organic phase was then added to the calorimeter. The temperature of the reaction solution would slowly increase due to the heat from the calorimeter housing and when it reached within about $20^{\circ} \mathrm{C}$ of the desired temperature, the solution was rapidly heated with the Peltier to temperature. This limited the amount of water and nitric acid loss due to evaporation and also allowed heat output measurements just after the onset of oxidation (visibly observable by the venting of brown $\mathrm{NO}_{2}$ fumes). The heat released or absorbed by the reaction was measured by recording the current supplied to the Peltier to hold the temperature constant at the calorimeter housing temperature. At least three thermocouples were being used and cross referenced during an experimental run. Two temperature measurements were taken of the calorimeter housing (both resting on the brass plate, Figure 1). One thermocouple was used for input to the temperature controller. Another thermocouple gave a reading of $\pm 0.1^{\circ} \mathrm{C}$ and was used to match the reaction solution temperature(s - if two phases). A third thermocouple (and sometimes a fourth) measured the temperature of the reaction solution, $\pm 0.1^{\circ} \mathrm{C}$. All thermocouples and thermometers used for measurements were checked for linearity and calibrated against a Kessler "calibrated " thermometer (S.N. 46691).

The gases released from the reaction solution are vented to atmospheric pressure through a 0.025 inch diameter restriction. The vented gases then entered either a dry-ice or an ice-water trap to condense out the low boiling point products. Due to concern for overheating by an acidbase reaction, no base was added to this trap as described in the Task Plan ${ }^{3}$. It was found that at ice-water temperatures the pressure produced by $\mathrm{HNO}_{2}$ in the trap was manageable during sample preparation. The noncondensable (and insoluble) gas products were then transferred to an inverted burette system. This allowed the capture and production rate measurement of gases such as $\mathrm{N}_{2}$, $\mathrm{NO}$, and $\mathrm{CO}_{2}$. Sample preparation of the condensed solution consisted of measuring the final volume, neutralizing and diluting the solution to a much larger known volume to dissolve all sparingly soluble organic compounds, and then sending samples of the resulting solution to Analytical Development Section (ADS) of Savannah River Technology Center (SRTC) for a variety of analyses. The total volume of the noncondensable gases was also measured. For specific experimental runs representative gas samples were taken and analyzed for the gaseous components and concentrations. 
WSRC-TR-94-0540

$\operatorname{Pg} 7$ of 45

\section{Heat Balance Calorimeter}

Measurements with the isothermal calorimeter (Runs 1 through 13) determined that a twolayered (organic and aqueous phase) reaction system was net endothermic. This brought out the question of the endothermic character of the organic phase with respect to increasing organic layer thickness. A nearly two foot tall dewar reaction vessel was designed and constructed and placed in an elevated temperature bath. The top portion of the dewar vessel was wrapped with glass wool, for insulation, and then surrounded with a plastic wind guard. The system, Figure 3 , was designed to perform as a "heat balance" calorimeter. A nichrome wire (in Teflon") heater was placed in the aqueous phase of the reaction solution to compensate for thermal heat loss from the system and to imitate the heating coils of an evaporator. A thermocouple was placed in each of the reacting liquid phases. Using an aluminum nitrate solution, the temperature bath could be heated to above $115^{\circ} \mathrm{C}$. The bath solution level was maintained at the same height as the initial reaction solution level to minimize heat transfer from the reacting system. The system was vented through a 0.116 inch diameter restriction.

The system was conservatively calibrated by placing $279 \mathrm{ml}$ ( 4 inches) of a solution (prepared, but not analyzed, to be $0.65 \mathrm{M} \mathrm{Fe}\left(\mathrm{NO}_{3}\right)_{3} / 0.7 \mathrm{M} \mathrm{Al}\left(\mathrm{NO}_{3}\right)_{3} / 6 \mathrm{M} \mathrm{HNO} \mathrm{HN}_{3}$ ) in the calorimeter reaction chamber with the bath preheated to $115^{\circ} \mathrm{C}$. The solution was heated with 73 watts power supplied by a Kepco DC Power Supply (T-0023310) to the nichrome wire. The voltage and current were measured by two Fluke multimeters (M\&TE\# WFQ-1306 \& EAQ-1857 respectively). The approximately four feet of nichrome wire was coiled and completely submerged in the aqueous phase. The ends were twist joined to two copper wires, one on each end, each also with about four inches submerged in the aqueous phase. The copper wiring then extended upward and out through a seal at the the top of the calorimeter housing. All of the wiring in contact with the reaction solution or vapors was sealed in a Teflon tube. A negligible amount of the power should have been dissipated in the copper portion of the wiring. Boiling of the solution started at $114^{\circ} \mathrm{C}$. The boiling point gradually increased and, after 34 minutes, had reached $118.3^{\circ} \mathrm{C}$, by which time $33.7 \mathrm{ml}$ of solution had condensed in trap). After evaporation of this much water the gas space in the reaction chamber, about $1300 \mathrm{ml}$, should have been completely purged of air. The solution was allowed to cool to $115^{\circ} \mathrm{C}$, the same temperature as the bath. The bath solution level and the solution in the reaction chamber were nearly the same. The power needed to hold the temperature at $115^{\circ} \mathrm{C}$ was 6.79 watts.

The above calibration should have been conservative with respect to the experimental runs for a two reasons. The height of the reacting solutions was higher, reducing the surface area for condensation heat loss. During experimental runs the system was constantly purging the gas space of any cooled gases because of the relatively large production rate of noncondensable gases. Especially because of this last factor the heat lost from the surface of the reacting solutions was probably negligible. Refluxing was not observable during the experimental runs. Except for the heat lost with the vented gases, which was desired, the reacting system was always conservative with respect to heat loss because the bath was always maintained above the temperature of the reacting solutions. The heat added to the reaction solution from the bath should be nearly linear with respect to the height and the temperature difference. Radiation heat transfer rate calculations give slightly high values with respect to the values extracted from the 
WSRC-TR-94-0540

$\mathrm{Pg} 8$ of 45

calibration and the experimental runs, Figure 4 . The heat input was approximately 0.073 watts per inch of solution height per degree centigrade temperature difference for the heat balance calorimeter system.

Performance of the heat balance calorimeter experimental runs was similar to the isothermal runs. The bath was preheated to $115^{\circ} \mathrm{C}$ and the two phases (aqueous and organic) were added simultaneously. In two of the three runs the nichrome wire was used at times as a heater. In general the most important data were the equilibrium temperatures of the two phases with respect to each other, the temperature of the bath, and the added heat (nichrome wire). Collection and measurement of condensate and noncondensable gases was performed as in the isothermal runs.

\section{RESULTS AND DISCUSSION}

\section{Isothermal Calorimeter (Runs \#1-13)}

Single Phase (Organic): There were a total of 9 successful single phase (organic) experimental runs performed at varying concentrations and temperatures. A total of 10 runs under varying conditions was originally mapped out to cover a wide range of conditions. The conditions covered the temperatures 85,110 , and $125^{\circ} \mathrm{C}$; the contacting nitric acid concentrations 5,10 , and $15.9 \mathrm{M} ; 50$ and $100 \mathrm{ml}$ of solution (to vary the volume to surface area ratio); and one run purged with $460 \mathrm{ml} /$ minute of helium gas. This original plan was changed as the experimental results were obtained and a better understanding of the system was developed. The conditions for the single phase runs are included in Table 1.

A plot of the heat output versus time for runs performed at $110^{\circ} \mathrm{C}, 10 \mathrm{M} \mathrm{HNO}$ contacting solution, and normalized to $100 \mathrm{ml}$ is shown in Figure 5. This plot shows an initial endothermic heat for some of the runs. This endothermic character is attributed to evaporation of water and nitric acid which are in relatively high concentration early in the run. A long heat-up time could account for the initial exothermic values measured for other runs. The experiments continued until the heat output began to decrease. Each run would have had to continue for more than eight hours to be completed. Stopping at the peak of heat output limited the duration of some runs to a few hours. The peak heat output for the runs 2 and 5 through 8 give a value of 0.72 \pm 0.32 watts (at $95 \%$ conf. limits). Since the balancing heat by the Peltier is dependent on sensing a temperature change in a given time frame the sensitivity of the calorimeter for $100 \mathrm{ml}$ is percentage wise only as good as for $50 \mathrm{ml}$. This heat output was lower than expected and resulted in canceling the runs to be performed at $85^{\circ} \mathrm{C}$. There was no correspondence found between volume and surface area, run \#5. This was later attributed to mixing caused by product bubble formation when it as found that stirring had no effect on the peak heat output either, run \#8. Purging the reaction vessel gas space with a helium purge of $460 \mathrm{ml} /$ minute may have slightly reduced the peak heat output, run \#10.

A plot of the heat output versus time for $100 \mathrm{ml}$ of TBP saturated with $10 \mathrm{M} \mathrm{HNO}_{3}$ 
WSRC-TR-94-0540

$\operatorname{Pg} 9$ of 45

\begin{tabular}{|c|c|c|c|c|c|}
\hline Run\# & Calorimeter & \#Phases & $\begin{array}{l}\text { Contacting } \\
{\left[\mathrm{HNO}_{3}\right]}\end{array}$ & $\begin{array}{l}\text { Temperature } \\
\left.{ }^{\circ} \mathrm{C}\right)\end{array}$ & $\begin{array}{c}\text { Unusual } \\
\text { Characteristic }\end{array}$ \\
\hline 2 & Isothermal & 1 & 10 & 110 & \\
\hline 3 & $"$ & 1 & 15.9 & $n$ & high acid \\
\hline 4 & " & 1 & 5 & " & low acid \\
\hline 5 & " & 1 & 10 & n & \\
\hline 6 & " & 1 & n & " & \\
\hline 7 & $n$ & 1 & n & " & \\
\hline 8 & " & 1 & n & " & unstirred \\
\hline 10 & " & 1 & n & $n$ & He purged $(460 \mathrm{ml} / \mathrm{min})$ \\
\hline 11 & " & 1 & " & 124 & high temperature \\
\hline 12 & " & 2 & n & 110 & $4 \mathrm{ml}$ aqueous $74 \mathrm{ml}$ organic final \\
\hline 13 & " & 2 & " & n & $1.3^{\prime \prime}$ organic/1.3" aqueous initial \\
\hline 14 & Heat-Balance & 2 & $\sim 11^{\mathrm{a}}$ & $114^{\mathrm{b}}$ & $2^{n}$ organic $/ 4^{n}$ aqueous \\
\hline 15 & $n$ & 2 & 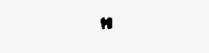 & $111^{\mathrm{b}}$ & $5^{n}$ organic/4" aqueous \\
\hline 16 & " & 2 & " & $105^{\mathbf{b}}$ & $8^{n}$ organic/4" aqueous \\
\hline
\end{tabular}

a - effective concentration (salt effect).

b - maximum temperature for run.

Table 1. Calorimetry Run (Experiments) Conditions

solution at $124^{\circ} \mathrm{C}$ (run \#11) is shown in Figure 6. Even though the variance in heat output per run is about \pm .4 watts, as can be seenin this plot the variance per data point is much lower in an individual run. This is because much of the error in heat output measurements from run to run is due to factors such as matching the temperature in the reaction solution chamber with the temperature of the isothermal calorimeter housing. The half-life for the reaction, due to the combined loss of nitric acid from the reaction and evaporation, at $124^{\circ} \mathrm{C}$ is about 100 minutes. The total "Net Heat" released for run \#11 was $5500 \pm 1500$ (27.6\%) calories with a peak net heat output of $2.6 \pm .3(11 \%)$ watts.

A plot of the off-gas rate versus time for run \#11 is shown in Figure 7 along with runs \# 3 through 8 , all normalized to $100 \mathrm{ml}$ of solution. Notice how the second order curve fit to the run \#11 data is shaped like the heat release data shown in Figure 6. When the relative initial reaction rates for the various reaction conditions are approximated by the off-gas rates at zero minutes, the nitric acid dependence of the reaction rate, Figure 8, and the activation energy, $\mathrm{E}_{\mathrm{a}}$, can be determined. At time zero, the nitric acid concentrations were considered to be those predicted by the saturation of TBP with varying concentrations of nitric acid ${ }^{4}$. The average offgas rate at time zero for runs \#5 through 8 was $5.62 \mathrm{ml} /$ minute $^{5}$. The off-gas rate for the $5 \mathrm{M}$ $\mathrm{HNO}_{3}$ and $110^{\circ} \mathrm{C}$ condition was assumed to be similar to its peak at 180 minutes, $3.60 \mathrm{ml} / \mathrm{min}$., since the reaction was slow to get started. The off-gas rate at $124^{\circ} \mathrm{C}$ was $18.06 \mathrm{ml} /$ minute giving 
WSRC-TR-94-0540

$\operatorname{Pg} 10$ of 45

a rough estimate for $E_{a}$ of $23.2 \mathrm{kcal} /$ mole with a frequency factor of $1.35 \mathrm{E} 15 \mathrm{~s}^{-15}$. This compares to a value of an $E_{a}$ of $26.8 \mathrm{kcal} / \mathrm{mole}$ with a frequency factor of $4.3 \mathrm{E} 10 \mathrm{~s}^{-1}$ determined by Nichols ${ }^{6}$. The condensation rate for run \#11 is shown in Figure 9. The filled circles show the condensation rate during heat up and prior to reaching $124^{\circ} \mathrm{C}$. Much of the water was lost before heat output measurements could be taken, resulting in strong exothermic behavior from the very beginning of the measurements.

Two-Phase (Organic and Aqueous): Two runs (\#12 and 13) were performed in the isothermal calorimeter with both organic and aqueous phases present. Both runs used an organic layer produced by saturating TBP with $10 \mathrm{M} \mathrm{HNO}_{3}$ solution. In each case a total of $100 \mathrm{ml}$ of solution was utilized with $25 \mathrm{ml}$ and $50 \mathrm{ml}$ of "fresh" $10 \mathrm{M} \mathrm{HNO}$ solution being used as the aqueous phase in the runs respectively. The two runs were performed either with only sufficient stirring to help transfer heat from the Peltier (\#12) or without stirring at all (\#13). In each case, once oxidation had begun in both phases, the reaction system became net endothermic. This was partially due to the lowering of the boiling point in the aqueous phase by butanol produced from hydrolysis of TBP. A plot of some of the reaction characteristics for run \#13 is shown in Figure 10. An input power of $2.94 \pm 0.3$ watts was needed to hold the aqueous phase temperature at $110^{\circ} \mathrm{C}$.

Runs $\# 3,5,11$, and 13 were performed in sufficient detail to perform mass (carbon and nitrogen), charge, and heat balances, Tables 2-5. The balance of carbon and nitrogen was determined by analysis of the initial and product solutions and gases ${ }^{3}$. An ice water bath was used in the condensate trap and was reasonably efficient at trapping condensables and $\mathrm{NO}_{2}$ (visually the brown $\mathrm{NO}_{2}$ fumes were removed from the gas stream at the condensate trap). The $\mathrm{NO}_{2}$ is trapped by

and

$$
\begin{aligned}
& 3 \mathrm{NO}_{2}+\mathrm{H}_{2} \mathrm{O}-->>2 \mathrm{HNO}_{3}+\mathrm{NO} \\
& 2 \mathrm{NO}_{2}+\mathrm{H}_{2} \mathrm{O}-\rightarrow>\mathrm{HNO}_{3}+\mathrm{HNO}_{2}
\end{aligned}
$$

The burette values, Tables 2-5, are from analysis of the $1250 \pm 10 \mathrm{ml}$ of solution used to trap the captured gas in the inverted burette. Missing material was attributed to solution left in the reaction vessel and held up in the transfer tubing between the traps (this should only account for a few percent). Analytical error was probably the main source of error which is typically $\pm 10 \%$ per analysis ${ }^{3}$. Looking at Run\# 13 in detail, Table 5; the carbon and nitrogen balances are 107.0 and $107.2 \%$ respectively. The carbon balance is a sum of the total organic carbon (TOC) results, adjusted to equivalent moles of TBP, and the $\mathrm{CO}_{2}$ and $\mathrm{CO}$ results. The charge balance shows that 0.125 moles $(45.3 \%$ ) of equivalent charge of oxidized (organic) species are missing. This is because no analysis was performed to determine the quantity of product carboxylic acids or other oxidized species in the resulting solutions. The stoichiometry for the net oxidation reaction was determined by simultaneously balancing the charge of the reduced and oxidized species; the ratios of acetic, propanoic, and butyric acids; and the heat addition and loss from the Peltier, oxidation reaction, TBP hydrolysis/esterification, and component evaporation. The experimental data was used to set the stoichiometry for the reaction. The moles of $\mathrm{CO}_{2}, \mathrm{CO}$, $\mathrm{N}_{2} \mathrm{O}, \mathrm{N}_{2}, \mathrm{HNO}_{2}$, $\mathrm{NO}$, and $\mathrm{NO}_{2}$ were held constant at the experimentally determined values for 


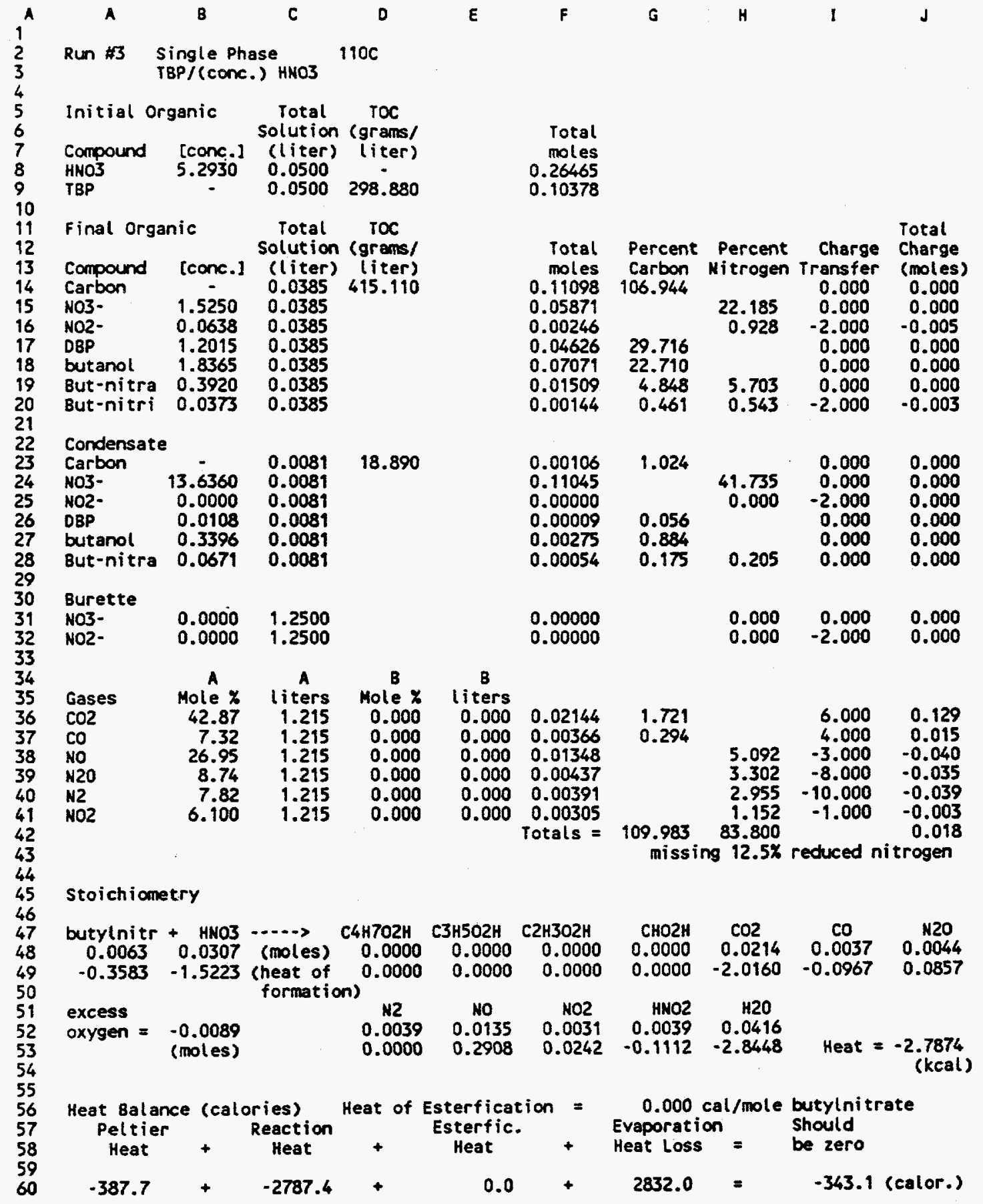

Table 2. Run $\# 3$ - Mass, Charge, and Heat Balance. Reaction Stoichiometry. 
WSRC-TR-94-0540

$\mathrm{Pg} 12$ of 45

\begin{tabular}{|c|c|c|c|c|c|c|c|c|c|}
\hline A & B & C & D & E & $F$ & G & H & 1 & J \\
\hline un $\# 5$ & Single $\mathrm{Ph}$ & $\begin{array}{l}\text { lase } \\
\text { INO3 }\end{array}$ & $110 \mathrm{c}$ & & & & & & \\
\hline $\begin{array}{l}\text { Initial } 0 \\
\text { Compound } \\
\text { HNO3 } \\
\text { TBP }\end{array}$ & $\begin{array}{l}\text { rganic } \\
\text { [conc.] } \\
3.6390 \\
-\end{array}$ & $\begin{array}{l}\text { Total } \\
\text { Solution } \\
\text { (liter) } \\
0.1000 \\
0.1000\end{array}$ & $\begin{array}{c}\text { Toc } \\
\text { (grams/ } \\
\text { (iter) } \\
- \\
433.790\end{array}$ & & $\begin{array}{r}\text { Total } \\
\text { moles } \\
0.36390 \\
0.30124\end{array}$ & & & & \\
\hline $\begin{array}{l}\text { Final Org } \\
\text { Compound } \\
\text { Carbon } \\
\text { NO3- } \\
\text { NO2- } \\
\text { OBP } \\
\text { butanol } \\
\text { But-nitra } \\
\text { But-nitri }\end{array}$ & $\begin{array}{l}\text { anic } \\
\text { [conc.] } \\
- \\
2.1103 \\
0.1333 \\
0.5101 \\
1.7543 \\
0.3338 \\
0.0299\end{array}$ & $\begin{array}{c}\text { Total } \\
\text { Solution } \\
\text { (liter) } \\
0.0930 \\
0.0930 \\
0.0930 \\
0.0930 \\
0.0930 \\
0.0930 \\
0.0930\end{array}$ & $\begin{array}{c}\text { Toc } \\
\text { (grams/ } \\
\text { liter) } \\
442.092\end{array}$ & & $\begin{array}{r}\text { Total } \\
\text { moles } \\
0.28552 \\
0.19626 \\
0.01240 \\
0.04744 \\
0.16315 \\
0.03104 \\
0.00278\end{array}$ & $\begin{array}{l}\text { Percent } \\
\text { Carbon } \\
94.780 \\
\\
10.499 \\
18.053 \\
3.435 \\
0.307\end{array}$ & 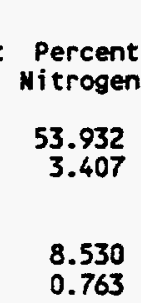 & $\begin{array}{r}\text { Charge } \\
\text { Transfer } \\
0.000 \\
0.000 \\
-2.000 \\
0.000 \\
0.000 \\
0.000 \\
-2.000\end{array}$ & $\begin{array}{c}\text { Total } \\
\text { Charge } \\
\text { (moles) } \\
0.000 \\
0.000 \\
-0.025 \\
0.000 \\
0.000 \\
0.000 \\
-0.006\end{array}$ \\
\hline $\begin{array}{l}\text { Condensat } \\
\text { Carbon } \\
\text { NO3- } \\
\text { NO2- } \\
\text { DBP } \\
\text { butanol } \\
\text { But-nitra }\end{array}$ & $\begin{array}{c}- \\
9.3040 \\
0.0661 \\
0.0558 \\
0.3331 \\
0.0712\end{array}$ & $\begin{array}{l}0.0065 \\
0.0065 \\
0.0065 \\
0.0065 \\
0.0065 \\
0.0065\end{array}$ & 11.539 & & $\begin{array}{l}0.00052 \\
0.06048 \\
0.00043 \\
0.00036 \\
0.00217 \\
0.00046\end{array}$ & $\begin{array}{l}0.173 \\
0.080 \\
0.240 \\
0.051\end{array}$ & $\begin{array}{r}16.619 \\
0.118 \\
0.127\end{array}$ & $\begin{array}{r}0.000 \\
0.000 \\
-2.000 \\
0.000 \\
0.000 \\
0.000\end{array}$ & $\begin{array}{r}0.000 \\
0.000 \\
-0.001 \\
0.000 \\
0.000 \\
0.000\end{array}$ \\
\hline $\begin{array}{l}\text { Burette } \\
\text { NO3- } \\
\text { NO2- }\end{array}$ & $\begin{array}{l}0.0000 \\
0.0000\end{array}$ & $\begin{array}{l}1.2500 \\
1.2500\end{array}$ & & & $\begin{array}{l}0.00000 \\
0.00000\end{array}$ & & $\begin{array}{l}0.000 \\
0.000\end{array}$ & $\begin{array}{r}0.000 \\
-2.000\end{array}$ & $\begin{array}{l}0.000 \\
0.000\end{array}$ \\
\hline $\begin{array}{l}\text { Gases } \\
\text { CO2 } \\
\text { CO } \\
\text { NO } \\
\text { N2O } \\
\text { N2 } \\
\text { NO2 }\end{array}$ & $\begin{array}{r}\text { A } \\
\text { Mole } x \\
34.32 \\
5.30 \\
41.14 \\
6.44 \\
8.16 \\
4.500\end{array}$ & $\begin{array}{c}A \\
\text { liters } \\
1.035 \\
1.035 \\
1.035 \\
1.035 \\
1.035 \\
1.035\end{array}$ & $\begin{array}{c}\text { B } \\
\text { Mole X } \\
0.000 \\
0.000 \\
0.000 \\
0.000 \\
0.000 \\
0.000\end{array}$ & $\begin{array}{c}B \\
\text { liters } \\
0.000 \\
0.000 \\
0.000 \\
0.000 \\
0.000 \\
0.000\end{array}$ & $\begin{array}{c}0.01462 \\
0.00226 \\
0.01752 \\
0.00274 \\
0.00348 \\
0.00192 \\
\text { Totals = }\end{array}$ & $\begin{array}{c}95.420 \\
\text { missi }\end{array}$ & $\begin{array}{r}4.815 \\
1.508 \\
1.910 \\
0.527 \\
91.729 \\
\text { ing } 32.2 \%\end{array}$ & $\begin{array}{r}6.000 \\
4.000 \\
-3.000 \\
-8.000 \\
-10.000 \\
-1.000 \\
\text { oxidized }\end{array}$ & $\begin{array}{r}0.088 \\
0.009 \\
-0.053 \\
-0.022 \\
-0.035 \\
-0.002 \\
-0.046 \\
\text { arbon }\end{array}$ \\
\hline \multicolumn{10}{|c|}{ Stoichionetry } \\
\hline $\begin{array}{l}\text { butylnitr } \\
0.0133 \\
-0.7578\end{array}$ & $\begin{array}{r}\text { HNO3 } \\
0.0342 \\
-1.6964\end{array}$ & $\begin{array}{l}\text { (moles) } \\
\text { (heat of } \\
\text { formation }\end{array}$ & $\begin{array}{l}: 44702 \mathrm{H} \\
0.0048 \\
-0.6124 \\
1)\end{array}$ & $\begin{array}{l}\text { C3H5O2H } \\
0.0038 \\
-0.4639\end{array}$ & $\begin{array}{l}\mathrm{C} 2 \mathrm{H} 3 \mathrm{O} 2 \mathrm{H} \\
0.0028 \\
-0.3240\end{array}$ & $\begin{array}{l}\text { CHO2H } \\
0.0000 \\
0.0000\end{array}$ & $\begin{array}{c}\operatorname{co2} \\
0.0146 \\
-1.3748\end{array}$ & $\begin{array}{c}c 0 \\
0.0023 \\
-0.0596\end{array}$ & $\begin{array}{l}N 20 \\
0.0027 \\
0.0538\end{array}$ \\
\hline $\begin{array}{l}\text { excess } \\
\text { oxygen = }\end{array}$ & $\begin{array}{r}0.0000 \\
\text { (moles) }\end{array}$ & & $\begin{array}{c}12 \\
0.0035 \\
0.0000\end{array}$ & $\begin{array}{l}\text { No } \\
0.0177 \\
0.3827\end{array}$ & $\begin{array}{c}\text { NO2 } \\
0.0021 \\
0.0170\end{array}$ & $\begin{array}{r}\text { HNO2 } \\
0.0152 \\
-0.4326\end{array}$ & $\begin{array}{c}H 20 \\
0.0330 \\
-2.2569\end{array}$ & Heat & $\begin{array}{r}-2.6167 \\
\text { (kcal) }\end{array}$ \\
\hline \multicolumn{3}{|c|}{$\begin{array}{c}\text { Heat } 8 \text { alance (calories) } \\
\text { Peltier } \\
\text { Heat }\end{array} \quad \begin{array}{c}\text { Reaction } \\
\text { Heat }\end{array}$} & \multicolumn{3}{|c|}{$\begin{array}{c}\text { Heat of Esterfication } \\
\text { Esterfic. }\end{array}$} & \multicolumn{2}{|c|}{$\begin{array}{l}=\quad 0 \mathrm{cal} / \mathrm{mole} \\
\text { Evaporation } \\
\text { Heat Loss }=\end{array}$} & $\begin{array}{l}\text { butylnit } \\
\text { Should } \\
\text { be zero }\end{array}$ & \\
\hline 822.4 & + & -2616.7 & & 0.0 & + & 2688.9 & $=$ & 894 & cal \\
\hline
\end{tabular}

Table 3. Run \#5 - Mass, Charge, and Heat Balance. Reaction Stoichiometry. 
WSRC-TR-94-0540

$\mathrm{Pg} 13$ of 45

\begin{tabular}{|c|c|c|c|c|c|c|c|c|c|}
\hline A & B & C & D & E & $\mathbf{F}$ & $G$ & $H$ & 1 & $\mathrm{~J}$ \\
\hline un $\# 11$ s & $\begin{array}{l}\text { ingle Pha } \\
\text { BP/10M HN }\end{array}$ & $\begin{array}{l}\text { lase } \\
\text { NO3 }\end{array}$ & $124 \mathrm{C}$ & & & & & & \\
\hline $\begin{array}{l}\text { Initial or } \\
\text { Compound } \\
\text { HNO3 } \\
\text { TBP }\end{array}$ & $\begin{array}{l}\text { ganic } \\
\text { [conc.] } \\
3.6500\end{array}$ & $\begin{array}{c}\text { Total } \\
\text { Solution } \\
\text { (liter) } \\
0.1000 \\
0.1000\end{array}$ & $\begin{array}{c}\text { TOC } \\
\text { (grans/ } \\
\text { (iter) } \\
- \\
433.798\end{array}$ & & $\begin{array}{r}\text { Total } \\
\text { moles } \\
0.36500 \\
0.30125\end{array}$ & & & & \\
\hline $\begin{array}{l}\text { Final Orga } \\
\text { Compound } \\
\text { Carbon } \\
\text { NO3- } \\
\text { NO2- } \\
\text { OBP } \\
\text { butanol } \\
\text { But-nitra } \\
\text { But-nitri }\end{array}$ & $\begin{array}{l}\text { Inic } \\
\text { [conc.] } \\
0 \\
0.0504 \\
0.0635 \\
0.6158 \\
3.0011 \\
0.3439 \\
0.0000\end{array}$ & $\begin{array}{c}\text { Total } \\
\text { Solution } \\
\text { (liter) } \\
0.0805 \\
0.0805 \\
0.0805 \\
0.0805 \\
0.0805 \\
0.0805 \\
0.0805\end{array}$ & $\begin{array}{c}\text { Toc } \\
\text { (grams/ } \\
\text { liter) } \\
434.783\end{array}$ & & $\begin{array}{r}\text { Total } \\
\text { moles } \\
0.24306 \\
0.00406 \\
0.00511 \\
0.04957 \\
0.24159 \\
0.02768 \\
0.00000\end{array}$ & $\begin{array}{l}\text { Percent } \\
\text { Carbon } \\
80.683 \\
\\
10.970 \\
26.732 \\
3.063 \\
0.000\end{array}$ & 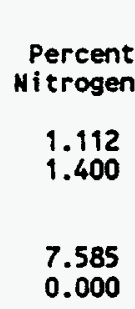 & $\begin{array}{c}\text { Charge } \\
\text { Transfer } \\
0.000 \\
0.000 \\
-2.000 \\
0.000 \\
0.000 \\
0.000 \\
-2.000\end{array}$ & $\begin{array}{c}\text { Total } \\
\text { Charge } \\
\text { (moles) } \\
0.000 \\
0.000 \\
-0.010 \\
0.000 \\
0.000 \\
0.000 \\
0.000\end{array}$ \\
\hline $\begin{array}{l}\text { Condensate } \\
\text { Carbon } \\
\text { NO3- } \\
\text { NO2- } \\
\text { DBP } \\
\text { butanol } \\
\text { But-nitra }\end{array}$ & $\begin{array}{l}8.6935 \\
1.3587 \\
0.1200 \\
1.8600 \\
0.7400\end{array}$ & $\begin{array}{l}0.0099 \\
0.0099 \\
0.0099 \\
0.0099 \\
0.0099 \\
0.0099\end{array}$ & 42.929 & & $\begin{array}{l}0.00295 \\
0.08607 \\
0.01345 \\
0.00119 \\
0.01841 \\
0.00733\end{array}$ & $\begin{array}{l}0.980 \\
0.263 \\
2.038 \\
0.811\end{array}$ & $\begin{array}{r}23.580 \\
3.685 \\
\\
2.007\end{array}$ & $\begin{array}{r}0.000 \\
0.000 \\
-2.000 \\
0.000 \\
0.000 \\
0.000\end{array}$ & $\begin{array}{r}0.000 \\
0.000 \\
-0.027 \\
0.000 \\
0.000 \\
0.000\end{array}$ \\
\hline $\begin{array}{l}\text { Buret te } \\
\text { NO3- } \\
\text { N02- }\end{array}$ & $\begin{array}{l}0.0051 \\
0.0211\end{array}$ & $\begin{array}{l}1.2500 \\
1.2500\end{array}$ & & & $\begin{array}{l}0.00638 \\
0.02638\end{array}$ & & $\begin{array}{l}1.747 \\
7.226\end{array}$ & $\begin{array}{r}0.000 \\
-2.000\end{array}$ & $\begin{array}{r}0.000 \\
-0.053\end{array}$ \\
\hline $\begin{array}{l}\text { Gases } \\
\text { CO2 } \\
\text { CO } \\
\text { NO } \\
\text { N2O } \\
\text { N2 }\end{array}$ & $\begin{array}{r}\text { A } \\
\text { Mole X } \\
36.96 \\
10.05 \\
31.50 \\
7.80 \\
11.74\end{array}$ & $\begin{array}{c}\text { A } \\
\text { liters } \\
1.933 \\
1.933 \\
1.933 \\
1.933 \\
1.933\end{array}$ & $\begin{array}{c}\text { B } \\
\text { Mole X } \\
33.090 \\
7.350 \\
35.550 \\
14.250 \\
12.780\end{array}$ & $\begin{array}{c}\text { B } \\
\text { liters } \\
1.633 \\
1.633 \\
1.633 \\
1.633 \\
1.633\end{array}$ & $\begin{array}{c}0.05164 \\
0.01293 \\
0.04895 \\
0.01578 \\
0.01793 \\
\text { Totals = }\end{array}$ & $\begin{array}{c}1.428 \\
0.358 \\
\\
83.449 \\
\text { missir }\end{array}$ & $\begin{array}{r}13.410 \\
8.647 \\
9.823 \\
80.222 \\
\text { ng } 23.74\end{array}$ & $\begin{array}{r}6.000 \\
4.000 \\
-3.000 \\
-8.000 \\
-10.000 \\
\\
\text { oxidized }\end{array}$ & $\begin{array}{r}0.310 \\
0.052 \\
-0.147 \\
-0.126 \\
-0.179 \\
-0.181 \\
\text { carbon }\end{array}$ \\
\hline oichion & $t$ & & & & & & & & \\
\hline $\begin{array}{r}\text { butynitr } \\
0.0514 \\
-2.9379\end{array}$ & $\begin{array}{c}\text { HNO3 } \\
0.1099 \\
-5.4453\end{array}$ & $\begin{array}{l}\text { (moles) } \\
\text { (heat of } \\
\text { formatio }\end{array}$ & $\begin{array}{l}\text { C4H702H } \\
0.0180 \\
-2.2966 \\
\text { on) }\end{array}$ & $\begin{array}{c}\text { C3H5O2H } \\
0.0150 \\
-1.8311\end{array}$ & $\begin{array}{c}\text { С2H302H } \\
0.0121 \\
-1.4001\end{array}$ & $\begin{array}{r}\text { CHO2H } \\
0.0000 \\
0.0000\end{array}$ & $\begin{array}{c}\operatorname{CO2} \\
0.0516 \\
-4.8565\end{array}$ & $\begin{array}{c}c 0 \\
0.0129 \\
-0.3417\end{array}$ & $\begin{array}{c}\text { N20 } \\
0.0158 \\
0.3095\end{array}$ \\
\hline $\begin{array}{l}\text { excess } \\
\text { oxygen }=\end{array}$ & $\begin{array}{r}0.0002 \\
\text { (moles) }\end{array}$ & & $\begin{array}{c}112 \\
0.0179 \\
0.0000\end{array}$ & $\begin{array}{c}\text { No } \\
0.0689 \\
1.4876\end{array}$ & $\begin{array}{c}\text { NO2 } \\
0.0199 \\
0.1580\end{array}$ & $\begin{array}{r}\text { HNO2 } \\
0.0051 \\
-0.1456\end{array}$ & $\begin{array}{c}H 20 \\
0.1427 \\
-9.7475\end{array}$ & Heat $=$ & $\begin{array}{r}-10.2809 \\
\text { (kcal) }\end{array}$ \\
\hline $\begin{array}{c}\text { Heat Balan } \\
\text { Peltier } \\
\text { Heat }\end{array}$ & nce (calo & $\begin{array}{l}\text { ories) } \\
\text { Reaction } \\
\text { Heat }\end{array}$ & $\begin{array}{r}\text { Heat } 0 \\
+\end{array}$ & $\begin{array}{c}\text { Esterficat } \\
\text { Esterfic. } \\
\text { Heat }\end{array}$ & tion $=$ & $\begin{array}{l}0.000 \\
\text { Evaporati } \\
\text { Heat Loss }\end{array}$ & $\begin{array}{l}\mathrm{cal} / \mathrm{mo} \\
\text { ion } \\
3^{2}=\end{array}$ & $\begin{array}{l}\text { butylnitr } \\
\text { Should } \\
\text { be zero }\end{array}$ & ate \\
\hline 5206.7 & + & -10280.9 & + & 0.0 & + & 3963.6 & $=$ & -1110.7 & (calor.) \\
\hline
\end{tabular}

Table 4. Run \#11 - Mass, Charge, and Heat Balance. Reaction Stoichiometry. 
WSRC-TR-94-05420

$\mathrm{Pg} 14$ of 45

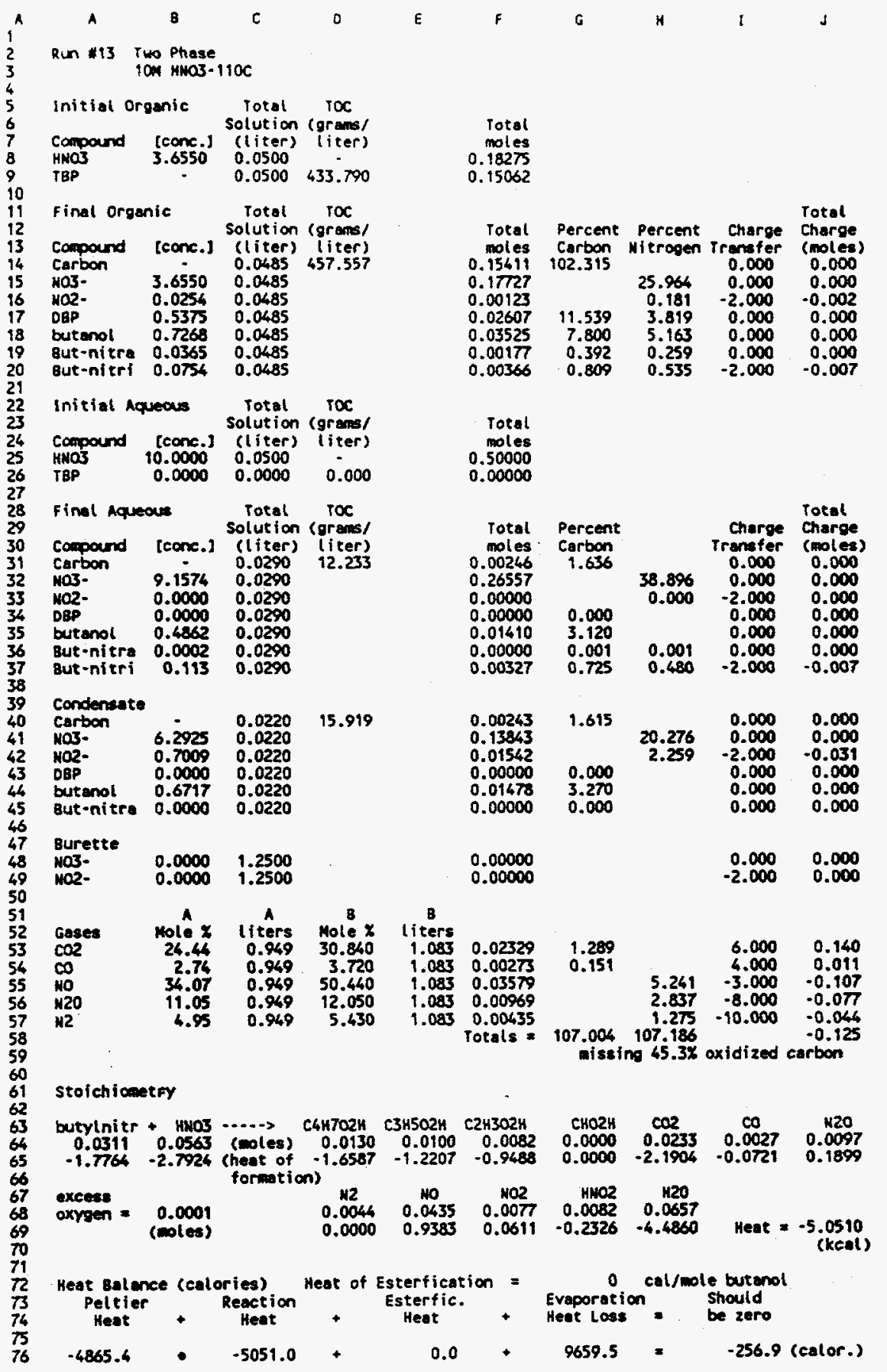

Table 5. Run \#13 - Mass, Charge, and Heat Balance. Reaction Stoichiometry. 
WSRC-TR-94-0540

$\operatorname{Pg} 15$ of 45

the calculation. The $\mathrm{HNO}_{3}$ and butylnitrate values were determined by the moles of nitrogen and carbon in the products respectively. The moles of water was determined by balancing the hydrogen from the other components. By varying the moles of product butyric, propanoic, and acetic acids an attempt was made to set the excess oxygen to zero, balance the 0.125 moles of excess charge (with $\mathrm{CO}_{2}$ set at +6 , each organic acid equaled +4 charge units), and set the net heat to zero simultaneously. With the charge essentially balanced (.001 moles) the heat balance was -256.9 calories, very close (missing cooling). This run, \#13, should have had the best heat balance since the oxidation rate and measurements were stable for a relatively long period, see Figure 10. Table 6 lists the resulting stoichiometries from Tables 2-5. Formic acid should be very unstable under these strongly oxidizing conditions. The nitrous acid (nitrite) observed in the condensate trap was assumed to be released from the reaction solution as

$$
2 \mathrm{HNO}_{2}-\cdots>\mathrm{H}_{2} \mathrm{O}+\mathrm{NO}+\mathrm{NO}_{2}
$$

The total volume of condensable material trapped during the time period for the heat balance calculations was $22.0 \mathrm{ml}$. The heat lost from evaporation of reaction products was negligible. The resulting volume was separated into aqueous and organic volumes (defined by the condensate TOC; Table 5). The $\mathrm{HNO}_{3}$ observed in the condensate was a product of evaporated $\mathrm{HNO}_{3}$ and released $\mathrm{NO}_{2}$, reactions (1a) and (1b). The heat of vaporization used for the condensate aqueous phases were approximated ${ }^{5,7}$ to be $358,420,425$, and 458 calories $/ \mathrm{ml}$ for runs $\# 3,5,11$, and 13 respectively. The organic portion was assumed to have a heat of vaporization the same as pure butanol, 114 calories $/ \mathrm{ml}^{5,7}$.

\section{Heat Balance Calorimeter (Runs \#14-16)}

Three runs (\#14-16) were performed using the heat balance calorimeter. Each run was performed with two layers (aqueous and organic) of reaction solution. In each case 4 inches, about $280 \mathrm{ml}$ of solution, of aqueous phase were used. The aqueous phase consisted of $0.65 \mathrm{M}$ $\mathrm{Fe}\left(\mathrm{NO}_{3}\right)_{3} / 0.7 \mathrm{M} \mathrm{Al}\left(\mathrm{NO}_{3}\right)_{3} / 6 \mathrm{M} \mathrm{HNO}_{3}$ solution giving a total of $10 \mathrm{M}$ nitrate. In the last run the aqueous phase was about $0.48 \mathrm{M} \mathrm{Fe}\left(\mathrm{NO}_{3}\right)_{3} / 0.36 \mathrm{M} \mathrm{Al}\left(\mathrm{NO}_{3}\right)_{3} / 8 \mathrm{M} \mathrm{HNO} \mathrm{HN}_{3}$ giving a total of about $10.52 \mathrm{M}$ nitrate. For runs \#15 and 16 the organic portion was shaken for five minutes with a five fold excess of aqueous phase to presaturate the solution. The initial thickness of the organic phase in the three runs was $2(139 \mathrm{ml}), 5(347 \mathrm{ml})$, and $8(556 \mathrm{ml})$ inches for runs \#14 through 16 respectively. Run \#14 was performed to ensure that the ferric ions (a mild oxidant) wouldn't cause any adverse reactions or catalyze the oxidation reaction. Figures 11 and 12 show the bath, aqueous phase, and organic phase temperatures versus time for runs $\# 15$ and 16 respectively. For both runs oxidation starts at about $94^{\circ} \mathrm{C}$ in the organic phase and at $102^{\circ} \mathrm{C}$ in the aqueous phase. Note how after bubbling started in the aqueous phase (filled circles), the temperature in the organic phase started to mirror the aqueous phase minus a few degrees. This is probably due to mixing of the solutions at the interface. 
REACTION STOICHIOMETRY (Runs\# 3, 5, 11, and 13)

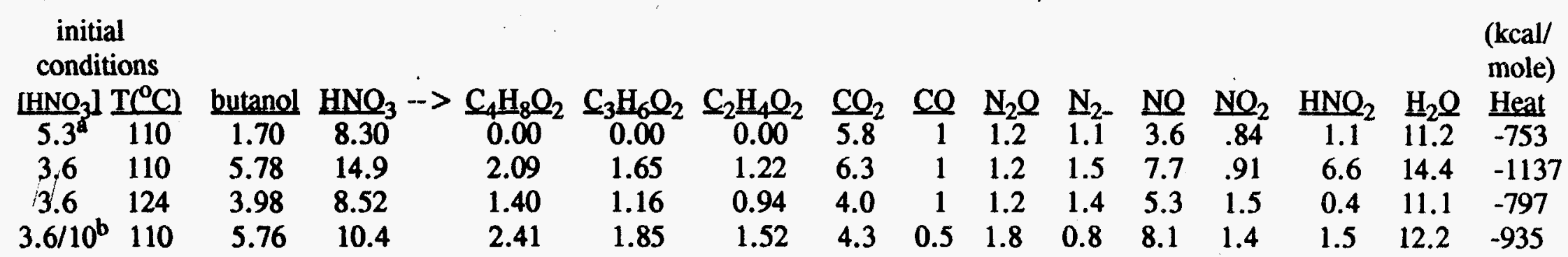

\begin{tabular}{|c|c|}
\hline \multicolumn{2}{|c|}{ initial conditions } \\
\hline$\left[\mathrm{HNO}_{3}\right]$ & $\mathrm{T}\left({ }^{\circ} \mathrm{C}\right)$ \\
\hline $5.3^{\mathrm{a}}$ & 110 \\
\hline 3.6 & 110 \\
\hline 3.6 & 124 \\
\hline $3.6 / 10^{b}$ & 110 \\
\hline
\end{tabular}

HEAT OUTPUT (kcal) PER

a - not good fit to data b - two-layered (aqueous and organic)

Table 6. Reaction Stoichiometries and Heats Per Measurable Quantity 
WSRC-TR-94-0540

$\operatorname{Pg} 17$ of 45

Oxidation Rate Dependence on Chemical Reactants

Nitric Acid ( $\left.\mathrm{HNO}_{3}\right) ;$ As discussed earlier, Figure 8 is a plot of the $\mathrm{HNO}_{3}$ dependence on the oxidation rate (proportional to the off-gas rate) in a single organic phase. This should also be the case for the organic phase of a two layered system. The oxidation rate in the aqueous phase (two layered system) is also possibly first order in $\left[\mathrm{HNO}_{3}\right]$ but probably has a very different oxidation rate due to the different mechanisms of the two phases. A plot of the Organic to Aqueous Thickness Ratio (one-dimensional reaction system) versus the Total Off-Gas Rate for runs \#12 through 16 is shown in Figure 13. There is no noticeable dependence on $\left[\mathrm{HNO}_{3}\right]$ in the range 6 to $10 \mathrm{M}$ (aqueous phase, the organic phase should be saturated with the respective aqueous phase). This plot points out that the oxidation rate in the aqueous phase is mass transfer limited. In other words, the rate is limited by the production and transfer, through the interface, of water soluble oxidation products, such as butyric and propanoic acids, in the organic phase. The total off-gas rate increases almost linearly up to an organic/aqueous ratio of about two. It then quickly levels off probably due to a limited oxidation rate in the aqueous phase.

Water $\left(\mathrm{H}_{2} \mathrm{O}\right)$ : The oxidation rate can depend on the $\left[\mathrm{H}_{2} \mathrm{O}\right]$ by affecting either the production of the primary oxidant, $\mathrm{NO}_{2}{ }^{8,9}$, or the production of fuel, butylnitrate. Figure 13 shows that the oxidation rate is mass transfer limited in the aqueous phase for this reaction system. There was no noticeable dependence on the $\left[\mathrm{H}_{2} \mathrm{O}\right]$ for oxidation in the organic phase (the data was fit by the rate expressions well with the dependence assumed zero order). The production of butanol by hydrolysis (or butylnitrate at higher $\left[\mathrm{HNO}_{3}\right]$ ) has been shown to be dependent only on the $\left[\mathrm{HNO}_{3}\right]$ and [TBP] in nitric acid solutions ${ }^{8}$. The oxidation reaction seems to have a zero order dependence on $\left[\mathrm{H}_{2} \mathrm{O}\right]$.

Butylnitrate: Since the off-gas rate is proportional to the oxidation rate Figure 7 in general leads to the conclusion that the overall oxidation rate expression is first order. Since the oxidation rate is first order in $\left[\mathrm{HNO}_{3}\right]$ the rate should be pseudo-zero order in [Butn]. Run \#4, Figure 7, is the lone exception and potentially points to a first order dependence on [Butn] at low [Butn]. Since reagent grade TBP was used in all of the tests the [Butn] should have initially been very low so a first order dependence on [Butn] could cause the shape seen in run \#4. Reactions that are overall second order when one of the reactants, say $B$, is in low concentration can become first order as the concentration of $B$ increases. The overall rate expression would have the form ${ }^{10}$

$$
\mathrm{d}[\mathrm{A}] / \mathrm{dt}=\mathrm{k}[\mathrm{A}]=\mathrm{a}[\mathrm{A}][\mathrm{B}] /(1+\mathrm{b}[\mathrm{B}])
$$

A plot of $1 / \mathrm{k}$ versus $[\mathrm{B}]^{-1}$ gives a straight line with a slope of $1 / \mathrm{a}$ and an intercept equal to $\mathrm{b} / \mathrm{a}$. This was performed with the data from run \#4 with the results $\mathrm{a}=3.54 \mathrm{E}-3 \mathrm{~min}^{-1}$ and $\mathrm{b}=2.86$ liters/mole. Using these numbers the off-gas rate for $10 \mathrm{M} \mathrm{HNO}_{3}$ contacted TBP (runs \#5-8) should be about twice that for run \#4 at 15 minutes time in Figure 7 (first data point for run \#4). As can be seen not any data points from runs $\# 5-8$ were at about $2.5 \mathrm{ml} / \mathrm{min}$ at 15 minutes. 
WSRC-TR-94-0540

$\mathrm{Pg} 18$ of 45

Statistics thus rules out this being a low [Butn] effect. For extra verification a calculation was made of the off-gas and Net Heat output profile versus time for TBP contacted with $10 \mathrm{M} \mathrm{HNO}_{3}$ and assuming that the oxidation rate was first order in [Butn] (in the same manner as will be discussed in the "Reaction Rates and Constants" section). The plot of this calculation is shown in Figure 14. The Net Heat curve looks generally correct but the off-gas rate doesn't resemble the data from runs \#5-8 (Figure 7). The conclusion is that the oxidation rate is pseudo-zero order in [Butn] down to at least about $0.1 \mathrm{M}$ [Butn]. During the performance of run $\# 4$ it was suspected that the slow build-up in the off-gas rate was caused by a relatively long induction period due to the low $\left[\mathrm{HNO}_{3}\right]$ in the organic phase, $\sim 2.6 \mathrm{M}$. An induction period is sometimes observed with oxidation by nitric acid because of its' autocatalytic nature? ${ }^{9}$.

\section{Cooling By Forced Evaporation}

The net endothermic character early in some of the single phase runs and for the duration of the two-phased runs led to the conclusion that the gaseous products formed during the oxidation $\left(\mathrm{CO}_{2}, \mathrm{CO}, \mathrm{N}_{2}, \mathrm{~N}_{2} \mathrm{O}\right.$, etc.) were forcing the evaporation of the volatile components (such as $\mathrm{H}_{2} \mathrm{O}, \mathrm{HNO}_{3}$, and butylnitrite) into the newly created gas space. This forced evaporation caused cooling that at times more than matched the heat produced from oxidation. The evaporation rate of the volatile components should be fast at temperatures near $100^{\circ} \mathrm{C}$, allowing the assumption that near partial pressure equilibrium is attained in the gas space before the bubbles escape. The amount of forced evaporation per unit of product gases generated was expected to be proportional to the total partial pressure of the volatile components and also related to the total pressure of the system. The ratio of the moles of volatile components forced out to the moles of gas produced should increase dramatically as the boiling point of the reacting solution is approached. The mole ratio of water evaporated to product gases released, $R_{\mathbf{m w}}$, from solution is given by

$$
\mathrm{R}_{\mathrm{mw}}=\mathrm{pp}_{\mathrm{w}} /\left(\mathrm{P}_{\mathrm{t}}-\mathrm{PVC}\right)
$$

where $\mathrm{pp}_{\mathrm{w}}$ is the partial pressure of water for the liquid phase in question, $\mathrm{P}_{\mathrm{t}}$ is the total pressure of the system, and PVC is the combined partial pressure of the volatile components. This is because $P_{t}-P V C$ is the combined partial pressure of the product gases. If the product gas production rate is known (or can be calculated) then the rate of water evaporation is directly proportional. The evaporation rate of the other volatile components is related to the oxidation product noncondensible gases in the same manner.

Equation (4) is a simplification which says that as PVC approaches $P_{t}, R_{m w}$ approaches infinity. This approximation fits the data reasonably well to within a few degrees of the boiling point. The mole ratio of condensate trapped to moles of noncondensable product gases generated is plotted in Figure 15 for runs \#13-16. For Figure 15 the exact boiling points were unknown, due to the build-up of volatile components such as butylnitrite, but were expected to be around $114^{\circ} \mathrm{C}$. The two curves have the shape expected for noncondensible gases being generated in $10 \mathrm{M} \mathrm{HNO}$. Run \#14 was heated, $\sim 70$ watts, for a prolonged period prior to the acquisition of these data points, which accounts for the curve being shifted right in Figure 15 since the 
WSRC-TR-94-0540

Pg 19 of 45

solution should have a relative higher boiling point. For both runs \#13 and 15 the maximum temperature was $110^{\circ} \mathrm{C}$ and both sets of data fit around the dashed curve. The lone data point from run \#16 resulted from a solution that had a maximum temperature of $103^{\circ} \mathrm{C}$ and was shifted the most left. Figure 15 shows that the mole ratio of condensate to product gas can be as high as 28 (this also supports the assumption that the volatile components are reaching near equilibrium with the noncondensible gases produced from the oxidation before escaping the solution).

This ratio increase near the boiling point should result in more net cooling per unit solution volume per unit of oxidation product gas generated. Figure \#16 shows a plot of the net cooling rate as a function of temperature for runs \#12-16. The solutions (aqueous and organic) in all of these runs should have had a boiling point near $114^{\circ} \mathrm{C}$. Note how the cooling rate of the solutions increase near the boiling point.

\section{REACTION RATES AND CONSTANTS}

\section{Single Phase (Organic)}

In order to extract the respective rate constants for the many physical and chemical processes affecting the concentrations of the various components, time dependent solutions were found for the differential equations governing the major chemical players. Since a run-away reaction in the organic phase is the main concern, the differential equations for nitric acid, water, and butylnitrate were derived for the organic phase (butanol should form the nitric acid ester at high nitric acid concentrations ${ }^{8}$ ). For a single phase system where the concentrations of water and butylnitrate stay relatively low compared to the nitric acid concentration the approximating equations are, for nitric acid

$$
-\mathrm{d}\left[\mathrm{HNO}_{3}\right] / \mathrm{dt}=\mathrm{n}_{1}\left[\mathrm{HNO}_{3}\right]+\mathrm{g}\left(\mathrm{P}_{\mathrm{ns}} /\left(\mathrm{N}_{\mathrm{s}}\left[\mathrm{P}_{\mathrm{t}}-\mathrm{PVC}\right]\right)\right)\left[\mathrm{HNO}_{3}\right]^{2}+\mathrm{n}_{3}\left[\mathrm{HNO}_{3}\right]
$$

where $n_{1}$ and $n_{3}$ are the rate constants for oxidation and hydrolysis respectively, $g$ is the production rate of noncondensible gas per liter of solution normalized to $1 \mathrm{M} \mathrm{HNO}_{3}(6.25 \mathrm{E}-4$ $\min ^{-1}$ at $110^{\circ} \mathrm{C}$ (approximated from runs $\# 5-8$ ), $N_{s}$ is the saturation concentration of nitric acid in the TBP after contact with nitric acid solution ${ }^{4}, \mathrm{P}_{\mathrm{t}}$ is the total pressure of the system, and PVC is the total partial pressure of the volatile components (mainly due to nitric acid, water, and butylnitrate). The second term defines the amount of nitric acid forced to evaporate by the oxidation production of noncondensible gases. Since the activities of the components should be the same in the two phases (organic and aqueous) at equilibrium the partial pressures of nitric acid, water, and butylnitrate in the organic phase at saturation; $\mathrm{p}_{\mathrm{ns}}, \mathrm{p}_{\mathrm{ws}}$, and $\mathrm{p}_{\mathrm{bs}}$, should be approximated by their pressures in the aqueous phase ${ }^{4}$. Since butylnitrate is mutually soluble in TBP its partial pressure is defined using Raoults' Law. Therefore (pns/ $\left.\left(\mathrm{N}_{\mathrm{s}}\left[\mathrm{P}_{\mathrm{t}}-\mathrm{PVC}\right]\right)\right)\left[\mathrm{HNO}_{3}\right]$ gives the mole ratio of nitric acid evaporated per unit volume of noncondensible gas produced $\left(\left(\mathrm{p}_{\mathrm{ns}} / \mathrm{N}_{\mathrm{s}}\right)\left[\mathrm{HNO}_{3}\right]\right.$ gives the partial pressure of $\left.\mathrm{HNO}_{3}\right) . \quad \mathrm{PVC}$ is given by 
WSRC-TR-94-0540

$\operatorname{Pg} 20$ of 45

$$
\mathrm{PVC}=\left[\mathrm{HNO}_{3}\right] \mathrm{p}_{\mathrm{ns}} / \mathrm{N}_{\mathrm{s}}+\left[\mathrm{H}_{2} \mathrm{O}\right] \mathrm{p}_{\mathrm{ws}} / \mathrm{W}_{\mathrm{s}}+[\mathrm{Butn}] \mathrm{p}_{\mathrm{bs}} / 8.84=\mathrm{pp}_{\mathrm{n}}+\mathrm{pp}_{\mathrm{w}}+\mathrm{pp}_{\mathrm{b}}
$$

where $W_{s}$ is the saturation concentration of water in TBP saturated with a specific concentration of nitric acid solution. Pure butylnitrite has a molar concentration of 8.84. Integrating and solving for $\left[\mathrm{HNO}_{3}\right]$ the solution is

$$
\left[\mathrm{HNO}_{3}\right]=\left[\mathrm{HNO}_{3}\right]_{0} \exp \{-\mathrm{n}(\mathrm{t})\} \quad \text { where } \mathrm{n}=\mathrm{n}_{1}+\mathrm{g}\left(\mathrm{p}_{\mathrm{ns}} /\left(\mathrm{N}_{\mathrm{s}}\left[\mathrm{P}_{\mathrm{t}}-\mathrm{PVC}\right]\right)\right)+\mathrm{n}_{3}
$$

For water

$$
\left.-d\left[\mathrm{H}_{2} \mathrm{O}\right] / \mathrm{dt}=\frac{\mathrm{g}\left(\mathrm{p}_{\mathrm{ws}} / \mathrm{W}_{\mathrm{s}}\right)\left[\mathrm{H}_{2} \mathrm{O}\right]}{\left[\mathrm{P}_{\mathrm{t}}-\left(\mathrm{PVC}_{\mathrm{n}, \mathrm{b}}\right)\right]-\left[\mathrm{H}_{2} \mathrm{O}\right]\left(\mathrm{p}_{\mathrm{ws}} / \mathrm{w}_{\mathrm{s}}\right)}\right)\left[\mathrm{HNO}_{3}\right]-\mathrm{w}_{2}\left[\mathrm{HNO}_{3}\right]
$$

where $\mathrm{PVC}_{n, b}$ is the partial pressure for "just" nitric acid and butylnitrate and $\mathrm{w}_{2}$ is the oxidation production rate of water (using $g$ and Table 4). Letting $\left[P_{t}-\left(P C_{n, b}\right)\right]=P T$ the solution is 5

$$
\begin{gathered}
\frac{\left[\mathrm{H}_{2} \mathrm{O}\right]}{\left(\mathrm{g}+\mathrm{w}_{2}\right)}-\frac{\left[\mathrm{H}_{2} \mathrm{O}\right]_{0}}{\left(\mathrm{~g}+\mathrm{w}_{2}\right)}+\frac{-\mathrm{g}\left[\mathrm{PT}\left(\mathrm{W}_{\mathrm{s}} / \mathrm{p}_{\mathrm{ws}}\right)\right.}{\left(\mathrm{g}+\mathrm{w}_{2}\right)^{\wedge} 2} \frac{\left(\mathrm{PT}\left(\mathrm{W}_{\mathrm{s}}\right)\left(\mathrm{w}_{2} / \mathrm{p}_{\mathrm{ws}}\right)\right)-\left(\mathrm{g}+\mathrm{w}_{2}\right)\left[\mathrm{H}_{2} \mathrm{O}\right]}{\left(\mathrm{PT}\left(\mathrm{W}_{\mathrm{s}}\right)\left(\mathrm{w}_{2} / \mathrm{p}_{\mathrm{ws}}\right)\right)-\left(\mathrm{g}+\mathrm{w}_{2}\right)\left[\mathrm{H}_{2} \mathrm{O}\right]_{0}} \\
=([\mathrm{HNO}] / n)\{1 \exp [-\mathrm{n}(\mathrm{t})]\}
\end{gathered}
$$

An iterative method was used to solve for $\left[\mathrm{H}_{2} \mathrm{O}\right]$ since it was algebraically inseparable ${ }^{5}$ For butylnitrate

$$
\mathrm{d}[\mathrm{Butn}] / \mathrm{dt}=\mathrm{b}_{1}\left[\mathrm{HNO}_{3}\right]-\mathrm{g}\left(\mathrm{p}_{\mathrm{bs}} /\left(8.84\left[\mathrm{P}_{\mathrm{t}}-\mathrm{PVC}\right]\right)\right)[\mathrm{Butn}]\left[\mathrm{HNO}_{3}\right]-\mathrm{b}_{3}\left[\mathrm{HNO}_{3}\right]
$$

$b_{1}$ and $b_{3}$ are the esterfication production and oxidation loss rates respectively. The second term gives the evaporation loss rate as described above. Letting $g\left(p_{b s} /\left(8.84\left[P_{t}-P V C\right]\right)\right)=b_{2}$ the solution is

$$
[B u t n]=\left[\left(b_{1}-b_{3}\right) / b_{2}\right]\left[1-\left\{\exp \left[\left(b_{2} / n\right)\left[H N O_{3}\right]_{0}(1-\exp [(-n) t])\right]\right\}^{-1}\right]
$$

A $2.43^{((T-110) / 10)}$ factor is used (defined by Nichols' data ${ }^{6}, \mathrm{E}_{\mathrm{z}}=26.8 \mathrm{kcal} / \mathrm{mole}$ ) to approximate the change in rate for the rate constants affected by temperature $\left(g, n_{1}, n_{3}, w_{2}, b_{1}\right.$, and $\left.b_{3}\right)$ when the temperature changes from $110^{\circ} \mathrm{C}$ (the temperature at which most of the data was acquired).

A simultaneous fit to runs $\# 5$ and 11 is shown in Figures 17 and 18 respectively. An approximate $\mathrm{g}$ value, $6.25 \mathrm{E}-4 / \mathrm{min}$, was determined from runs $\$ 5-8$ as a starting point since the nitric acid and water concentrations should have been only slightly reduced during the heat-up period. The best fit $\mathrm{g}$ value, $7.0 \mathrm{E}-4 / \mathrm{min}$, and the appropriate reaction stoichiometries, Tables $\# 3$ and 4 , were used to determine the rate expressions rate constant values. The values for $n_{1}$, $w_{2}$, and $b_{3}$, that best fit both runs (representing 110 and $124^{\circ} \mathrm{C}$ ) are $5.4 \mathrm{E}-4,6.1 \mathrm{E}-4$, and $2.3 \mathrm{E}-4$ 
WSRC-TR-94-0540

$\mathrm{Pg} 21$ of 45

$\min ^{-1}$ respectively. $n_{3}$ and $b_{1}$ were equivalent and determined using Nichols' hydrolysis rate ${ }^{6}$ and assuming that the rate of hydrolysis decreases proportionally with the number of phosphatebutanol ester groups available in the organic phase (DBP and MBP as well as TBP), giving (using) on average a hydrolysis rate constant of $1.25 \mathrm{E}-3 \mathrm{~min}^{-1}$ for the calculation. PVC and $\mathrm{PVC}_{\mathrm{n}, \mathrm{b}}$ were approximated during the calculations using the same assumptions described earlier and chosen to match the total pressure due to the volatile components at the peak heat output; these two values typically dropped from about 600 to $450 \mathrm{~mm} \mathrm{Hg}$ during the course of the simulated reaction.

The observed $\left[\mathrm{HNO}_{3}\right]$ for run \#5, Figure 17, was lower than that predicted in the calculation probably because of it being in equilibrium with its reduction species (in other words it is reduced by NO). The [butylnitrate] is probably high because of hydrolysis after completion of the reaction but before analysis, $\mathrm{HNO}_{3}$ reduction products seem to accelerate the hydrolysis of TBP ${ }^{6,8}$. The maximum calculated Net Heat was about 6.5 watts/liter for run $\# 5$ which compares well with an average of 7.2 \pm 3.2 watts/liter for runs \#5-8. The calculated off-gas rate generally fits the data. The fit to run \#11 was more revealing because the reaction was performed to near completion. Once again the $\left[\mathrm{HNO}_{3}\right]$ was low and the [butylnitrate] slightly high, both probably for the same reasons. The calculated off-gas rate fits the data well. The calculated Net Heat gave a value much too high at the end of the reaction until it was assumed that $1 / 2$ of the calculated butylnitrate was reduced to butylnitrite. Butylnitrite was observed by analysis for some of the runs but should be very sensitive to air oxidation in acid solution, similar to nitrous acid. Butylnitrite has a much higher partial pressure, b.p. $=77.8^{\circ} \mathrm{C}$, than butylnitrate, b.p. $=135.5^{\circ} \mathrm{C}$, and is probably the source of the butanol compounds found in the condensate (it may also have been the source of the nitrous acid, blue in color, in the deep blue condensate).

\section{Two Phase (Organic and Aqueous)}

Even though a two phase (aqueous and organic) oxidizing system has more modes for interaction, in many ways the system is simpler to model mathematically. This is because rapid transfer of material between the two phases due to bubble-induced mixing at the interface causes the reagent concentrations to stay nearly constant or to rapidly reach an equilibrium concentration. Unlike the rapid drop in $\left[\mathrm{HNO}_{3}\right]$ seen in the single organic phase reaction, in a two phase system the $\left[\mathrm{HNO}_{3}\right]$ in the organic phase can be assumed to stay constant and near the saturation concentration which is defined by the aqueous phase $\left[\mathrm{HNO}_{3}\right]$. The water concentration reaches a rapid equilibrium also because of rapid mixing between the two phases ${ }^{2}$. Mixing also occurs in the downward direction, from organic to aqueous phase, almost as quickly as the reverse direction ${ }^{2}$. This allows transfer of water soluble organic oxidation products (such as butyric and propanoic acids), produced mainly in the organic phase ${ }^{8}$, to replenish the quantity lost by its oxidative depletion in the aqueous phase. Oxidation in the aqueous phase is the main driving force for mixing of the interface ${ }^{2}$. Since the dependence for butylnitrate on the oxidation rate is zero order down to concentrations of at least a few molar the mixing butylnitrate transfer rate should be sufficiently fast. The off-gas rate from the aqueous phase was always as expected 
WSRC-TR-94-0540

$\mathrm{Pg} 22$ of 45

for a given $\left[\mathrm{HNO}_{3}\right]$ thus the experimental data supports this conclusion. The assumption that the limitation for organic material being transferred to the aqueous phase is proportional to the concentration of butanol (and its derivatives) and there solubilities is probably very conservative since many of the oxidation intermediates (such as butanoic and propanoic acid) are very soluble in the aqueous phase and constantly being generated in the organic phase.

The two phase calculations assume that the system is in an original state of being heated to the point of rapidly evaporating the liquid portion, mainly water. Rapid mixing at the interface would keep the $\left[\mathrm{H}_{2} \mathrm{O}\right]$ near the saturation level. At the point the heat is turned off or greatly reduced the organic phase $\left[\mathrm{H}_{2} \mathrm{O}\right]$ would drop to a lower equilibrium concentration defined by its loss due to evaporation and gains through oxidation and transfer of water by bubble mixing from the aqueous phase. The $\left[\mathrm{H}_{2} \mathrm{O}\right]$ at a given time is key in defining the Net Heat of the organic phase given by ${ }^{5}$

Net heat $(\mathrm{H})=($ esterfication + oxidation heat $)$ - evaporation heat

$H=H_{e}+g\left[H N O_{3}\right]\left\{\left(\frac{(.0697) H_{o}}{m}-\frac{(677)\left[\mathrm{H}_{2} \mathrm{O}\right]\left(\mathrm{p}_{\mathrm{ws}} / \mathrm{W}_{\mathrm{s}}\right)+(505) \mathrm{pp}_{\mathrm{n}}+(555) \mathrm{pp}_{\mathrm{b}}}{\mathrm{P}_{\mathrm{t}}-\left\{\left[\mathrm{H}_{2} \mathrm{O}\right]\left(\mathrm{p}_{\mathrm{ws}} / \mathrm{W}_{\mathrm{s}}\right)+\mathrm{PVC}_{\mathrm{n}, \mathrm{b}}\right\}}\right.\right.$

move the first two terms on the right side to the left and set this $=A$, then solve for $\left[\mathrm{H}_{2} \mathrm{O}\right]$

$$
\left[\mathrm{H}_{2} \mathrm{O}\right]=\frac{\mathrm{A}\left(\mathrm{P}_{\mathrm{t}}-\mathrm{PVC}_{\mathrm{n}, \mathrm{b}}\right)-(505) \mathrm{pp}_{\mathrm{n}}-(555) \mathrm{pp}_{\mathrm{b}}}{\left((677) \mathrm{p}_{\mathrm{ws}} / \mathrm{W}_{\mathrm{s}}\right)+\left(\mathrm{A}\left(\mathrm{p}_{\mathrm{ws}} / \mathrm{W}_{\mathrm{s}}\right)\right)}
$$

where $\mathrm{H}_{e}, \mathrm{H}_{\mathrm{o}}$, and $\mathrm{m}$ are the heat of esterfication (near zero), oxidation, and a proportionality constant relating the heat per unit off-gas respectively. $\mathrm{pp}_{\mathrm{n}}$ and $\mathrm{pp}_{\mathrm{b}}$ are the "actual" partial pressures of $\mathrm{HNO}_{3}$ and butylnitrate. The other terms are as defined earlier. The constants were chosen to give heat in watts.

For a two-phase system at equilibrium the $\left[\mathrm{H}_{2} \mathrm{O}\right]$ in the organic phase is 5

$-\mathrm{d}\left[\mathrm{H}_{2} \mathrm{O}\right] / \mathrm{dt}=0=$ evaporation loss - oxidation production - transfer rate from aqueous phase

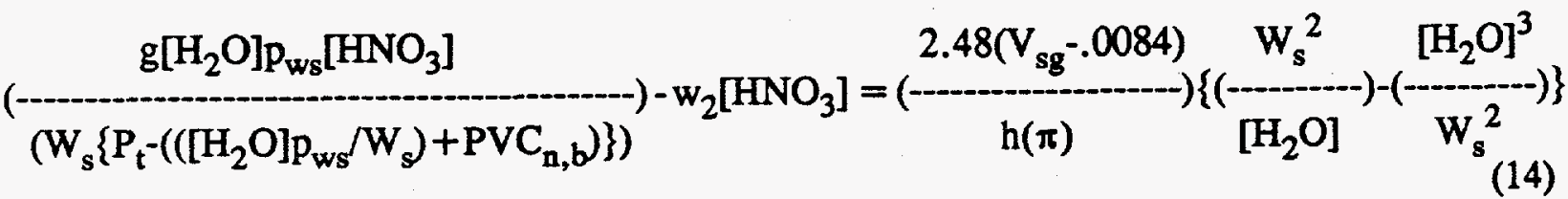

where $h$ is the organic layer in units of aqueous layer height, $v_{s g}$ is the superficial gas velocity $\left(\mathrm{ml} / \mathrm{min} \mathrm{cm}^{2}\right)$ in the aqueous phase, and the constants relate $\mathrm{V}_{\mathrm{sg}}$ to the dispersion coefficient ${ }^{2}$. Letting the left side $=B$, and solving for $h^{5}$ 
WSRC-TR-94-0540

$\operatorname{Pg} 23$ of 45

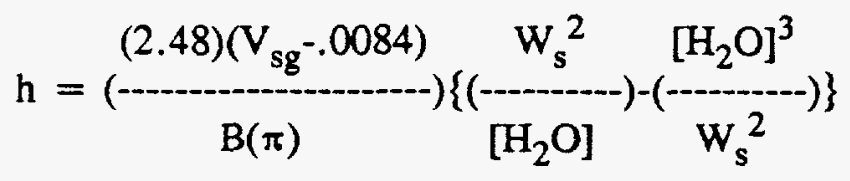

where the constants relate the mixing transfer rate ${ }^{2} . \mathrm{V}_{\mathrm{sg}}$ is given by

$$
\mathrm{V}_{\mathrm{sg}}=\mathrm{g}\left(760 / \mathrm{P}_{\mathrm{ti}}\right)(740.66)\left[\mathrm{HNO}_{3} \text { aqueous }\right]\left\{1+\left(\mathrm{PVC}_{\mathrm{w}, \mathrm{n}} /\left(\mathrm{P}_{\mathrm{ti}}-\mathrm{PVC}_{\mathrm{w}, \mathrm{n}}\right)\right)\right\}
$$

where the first constant converts $\mathrm{g}$ to the velocity $\left(\mathrm{ml} / \mathrm{min} \mathrm{cm}^{2}\right)$ of noncondensible gas produced from one foot of aqueous phase. The value of $g$, as mentioned earlier, is already been corrected for a change in temperature (for calculation of $\mathrm{V}_{\mathrm{sg}}$ the temperature of the aqueous phase should be used). Only water and $\mathrm{HNO}_{3}$ are employed for the total partial pressure of volatile components, $\mathrm{PVC}_{\mathrm{w}, \mathrm{n}}$, since the organic compounds in the aqueous phase are oxidized quickly and should therefore be low in concentration. $P_{t i}$ is the total pressure at the interface, includes the atmospheric and organic layer weight components. The 1 factors in the noncondensible gas contribution to the gas velocity since the last part of this term relates only the volacile components contribution.

By incorporating equation (13) and (16) into equation (15) an approximate height can be determined for a given set of conditions (including Net Heat for the organic phase). The results of such calculations are given in Table 7. The first two calculations (rows) in Table 7 represent actual experimental data from runs \#16 and 13 respectively. The partial pressures for the solution components were approximated as described earlier. The partial pressure used for butylnitrate and nitrite was approximated assuming the molar concentrations were equivalent. This combination gives the best fit and this assumption is on average supported by the experimental data. For runs $\# 16$ and $13, P_{t}$ was set to the ambient pressure $(760 \mathrm{~mm} \mathrm{Hg})$, this assumed that partial pressure equilibrium was obtained between the liquid and gas phases. The $P_{t i}$ values used were the sum of the ambient pressure and the weight of the organic layer, in pressure units, using the density values for TBP saturated with the aqueous phase $\left[\mathrm{HNO}_{3}\right]^{4}$. For these two calculations the concentration of the combined butylnitrate and nitrite concentrations, [Butn], was varied until the correct height (actually height ratio since the equations were normalized to one foot of aqueous phase) was produced. Using a ratio in this manner should

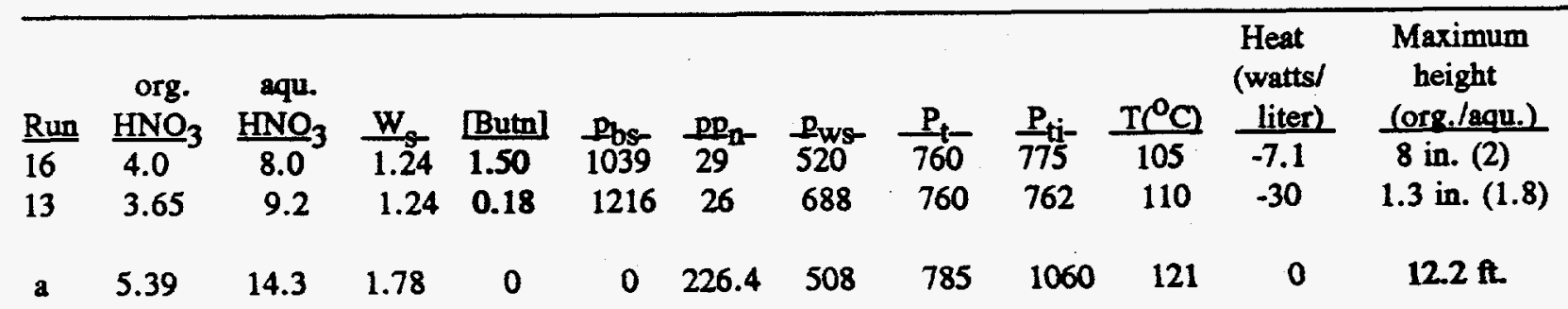

a - worst case scenario, $15 \mathrm{M} \mathrm{HNO}_{3}$ (aqueous phase) within one degree of the boiling point.

Table 7. Organic Thickness Supported by One Foot of Aqueous Phase. 
only be possible when $P_{t i}$ is near the ambient pressure. The value of [Butn] was then compared to the experimentally determined value. The value for run $\# 13$ was about $0.42 \mathrm{M}$ which resembles the calculated value of $0.18 \mathrm{M}$ (some esterfication of TBP may have occurred after the run was completed). The value for nun \#16 was not determined but should have been less than the $1.5 \mathrm{M}$ value calculated; using the esterfication rate $1.33 \mathrm{E}-3$ the maximum should have been $0.94 \mathrm{M}$ not counting oxidation loss (the experimental DBP concentration points to [Butn] in the lower range). Again esterfication may have occurred after completion of the run.

The worst case scenario is shown in the last calculation, row, of Table 7. The temperature used was chosen to give a condensate to off-gas mole ratio of 28 , which was the highest observed experimentally, Figure 15 . This ratio represents a solution temperature about one degree Centigrade below the boiling point. This ratio is physically limited by the inability of the volatile components to maintain partial pressure equilibrium in the generated gas bubbles at high oxidation rates. The limit of this ratio was not measured, in fact it might reach well above a hundred, but the value of 28 will be used as a conservative limit. Since the boiling point of $14.3 \mathrm{M} \mathrm{HNO}_{3}$ solution is about $122^{\circ} \mathrm{C}$, the maximum height, $\mathrm{h}$, is calculated at a temperature of $121^{\circ} \mathrm{C}$ ( $\sim 730 \mathrm{mmHg}$ partial pressure), this automatically sets the mole ratio to 28 . The ratio defined by $P_{t i}$ at the interface will be much smaller. To be conservative [Butn] was set to zero. The partial pressures for $\mathrm{H}_{2} \mathrm{O}$ and $\mathrm{HNO}_{3}$ were approximated to be 508 and $226.4 \mathrm{~mm} \mathrm{Hg}$ respectively. The saturation concentrations of $\mathrm{H}_{2} \mathrm{O}$ and $\mathrm{HNO}_{3}$ in TBP saturated with $15 \mathrm{M}$ $\mathrm{HNO}_{3}$ is 1.78 and $5.39 \mathrm{M}$ respectively ${ }^{4}$. An amount of pressure $(25 \mathrm{~mm} \mathrm{Hg})$ equal to one foot of organic phase, density 1.0955 grams $/$ liter $^{4}$ ) was added to the ambient pressure to obtain $P_{t}$, accounts for incomplete saturation of the volatile components, being conservative. The full weight of the organic layer was added to the ambient pressure to get $P_{t i}$. The calculated worst case value of 12.2 feet is conservatively low for another reason not mentioned earlier. The temperature of the aqueous phase was experimentally found to hover about one degree Centigrade above the organic phase temperature. This is probably due to a much larger concentration of butylnitrite in the organic phase than in the aqueous phase since it is susceptible to hydrolysis, producing butanol and nitric acid, in the aqueous phase. Butylnitrite has an appreciable partial pressure at these elevated temperatures (b.p. $77.8^{\circ} \mathrm{C}$ ) and will therefore contribute strongly to the total pressure of the volatile components and therefore evaporative heat loss. The temperature of the organic phase might be lower if not held up by coupling with the aqueous phase (heat/mass transfer due to bubble mixing at the interface). A correction in the temperature would increase $\mathrm{V}_{\mathbf{s g}}$ in favor of better cooling since the temperatures were assumed equivalent for the calculations.

\section{CONCLUSIONS}

These calorimetry studies have determined that the heat released per unit of butylnitrate (nitrite) oxidized and the oxidation rate is less in an open system than in a closed "pressurized" system $^{6}$. This is due mainly to a lower solution concentration and reduced utilization of the $\mathrm{HNO}_{3}$ reduction products, which are also oxidants. The oxidation rate was approximated to be 
WSRC-TR-94-0540

$\operatorname{Pg} 25$ of 45

5.4E-4 $\mathrm{min}^{-1}$ for an open vented system as compared to $1.33 \mathrm{E}-3 \mathrm{~min}^{-1}$ in the closed system used by $\mathrm{Nichols}^{6}$. The open system resulted in a much lower fraction of the $\mathrm{HNO}_{3}$ being reduced to $\mathrm{N}_{2}$ or $\mathrm{N}_{2} \mathrm{O}$. The overall stoichiometry was found to be similar for a single (organic) and twolayered (organic and aqueous) system which means that the heat produced per unit of fuel oxidized is also the same. The oxidation was found to be first order in nitric acid in the organic phase and pseudo-zero order in butylnitrate and water. Oxidation in the aqueous phase was found to be mass transfer limited at low organic to aqueous height ratios, below a ratio of 4 . The esterfication (hydrolysis) rate determined by Nichols' $\left(1.33 \mathrm{E}-3 \mathrm{~min}^{-1}\right)$ was found to fit the experimental data from this work well and was used in the single layer calculations.

The Net Heat for the system is dependent on the water content of the solution (and to a lesser degree on other volatile components). As the oxidation product gases start to form the volatile liquids in the solution evaporate into the gas space maintaining their partial pressures. This forced evaporation is a cooling mechanism which can more than balance the heat from the oxidation reaction. The Net Heat, therefore, can be endothermic resulting in the solution cooling down under its' own power. For a two layered system the net endothermicity is maintained by mixing of the interface by gas produced from oxidation in the aqueous phase.

Calculations give a conservative upper limit for the maximum organic thickness supported by one foot of "reacting" aqueous phase consisting of $14.3 \mathrm{M} \mathrm{HNO}_{3}$ at $121^{\circ} \mathrm{C}$ of $12.2 \pm 6.0$ feet. This temperature $\left(121^{\circ} \mathrm{C}\right.$ ) and acid concentration (14.3M) for the aqueous phase, in combination, define the worst case scenario for the calculations. Mixing at the interface, caused by bubbles formed from oxidation in the aqueous phase, was found experimentally and through calculation ${ }^{2}$ to maintain the reactants near the saturation limit. The actual supportable height is probably more than double this conservative value. Oxidation in the organic phase alone does not produce sufficient transport of water from the aqueous to the organic phase to maintain net cooling in the organic phase ${ }^{2}$. If oxidation isn't occurring in the aqueous phase, the organic phase could lose water and heat up (if loss of heat to the environment by other modes won't make up for the heat released from oxidation in the organic phase).

If the pressure in a reacting system is allowed to increase (say due to insufficient venting) the temperature of the organic phase would increase in temperature in an attempt to reach a new equilibrium. The rate of oxidation would increase not only due to the increase in temperature but also from the increased concentration of dissolved $\mathrm{HNO}_{3}$ reduction products ${ }^{9}$. Another complication factor is that the cooling system described in this work is rapidly reduced by an increase in the total pressure. These factors probably contributed to the explosion at Tomsk.

\section{ACKNOWLEDGEIMENTS}

The help rendered by Charles Crawford (Research Associate at SRTC) in support of the gas sample analysis of the reaction products is greatly appreciated. Discussions with George $\mathbf{S}$. Nichols (CPT/STRC), M. Lee Hyder (CPT/SRTC), Major C. Thompson (CPT/SRTC), and Don F. Paddleford (STD/SRTC) have been very useful in understanding the chemistry and processes of the TBP/HNO $\mathrm{HN}_{3}$ system. Don F. Paddleford is also appreciated for his pursuit of a thorough understanding of the mechanisms and processes involved in this study. 
WSRC-TR-94-0540

$\mathrm{Pg} 26$ of 45

\section{REFERENCES}

1) J.R. Smith, P. Zanonato, and G. Choppin, J. Chem. Thermodynamics, 24, 99 (1992).

2) J.E. Laurinat, Mass Transfer Model for Two-Layer TBP Oxidation Reactions, WSRCTR-94-0437, Savannah River Site, Aiken, SC 29808.

3) J.R. Smith, Task and QA Plan - Isothermal Heat Production from a TBP/HNQ 3 Solution (U), WSRC-RP-94-489, Savannah River Site, Aiken, SC 29808.

4) W. Davis, Jr., J. Mrochek, and C. J. Hardy, J. Inorg. Nucl. Chem., 28, 2001 (1966).

5) J.R. Smith and W.S. Cavin, Reaction Characteristics of TBP/Nitric Acid Systems (U), X-CLC-F-00063, Savannah River Site, Aiken, SC 29808.

6) G.S. Nichols, Decomposition of the Tributyl Phosphate-Nitrate Complexes, DP-526, Savannah River Site, Aiken, SC 29808.

7) R.H. Perry, D.W. Green, and J.O. Maloney, Perry's Chemical Engineers' Handbook, $6^{\text {th }}$ Ed., McGraw-Hill Book Company, New York, NY, 1984.

8) W.W. Schulz and J.D. Navratil, Science and Technology of Tributyl Phosphate, Vol. 1, CRC Press, Inc., Boca Raton, Florida (1984).

9) J.R. Smith, Air-Nitric Acid Destructive Oxidation of Organic Wastes, WSRC-MS-93-169, Savannah River Site, Aiken, SC 29808.

10) R.G. Wilkins, The Study of Kinetics and Mechanism of Reactions of Transition Metal Complexes, Allyn \& Bacon, Inc., Boston, MA, (1974). 
WSRC-TR-94-0540

$\mathrm{Pg} 27$ of 45

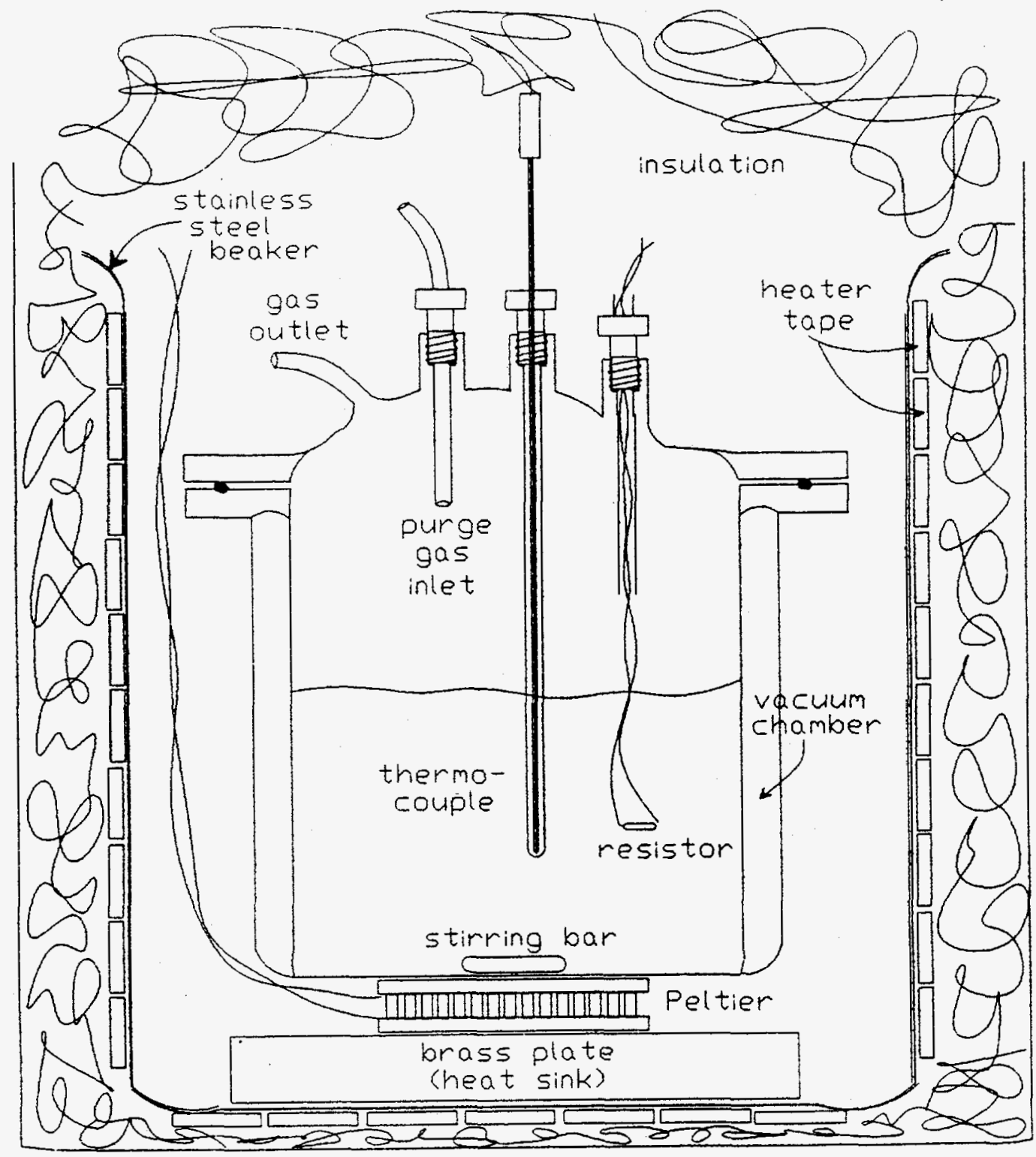

Figure 1. Isothermal (Peltier) Calorimeter 
WSRC-TR-94-0540

$\mathrm{Pg} 28$ of 45

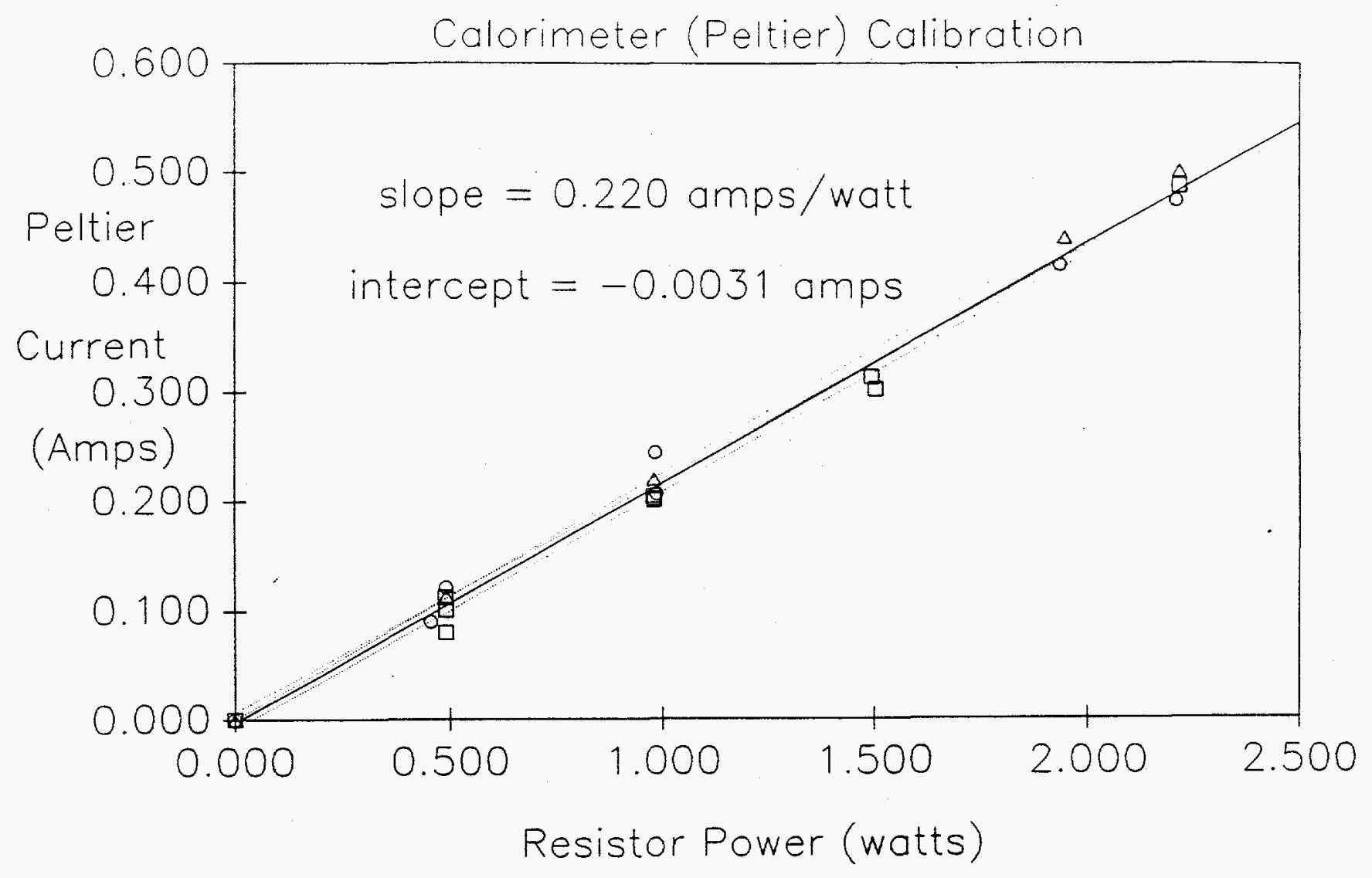

$\circ-110^{\circ} \mathrm{C}$ and $50 \mathrm{ml}$ solution

口 $-110^{\circ} \mathrm{C}$ and $100 \mathrm{ml}$ solution

$\Delta-125^{\circ} \mathrm{C}$ and $100 \mathrm{ml}$ solution

Figure 2. Isothermal Calorimeter Calibration. 
WSRC-TR-94-0540

$\mathrm{Pg} 29$ of 45

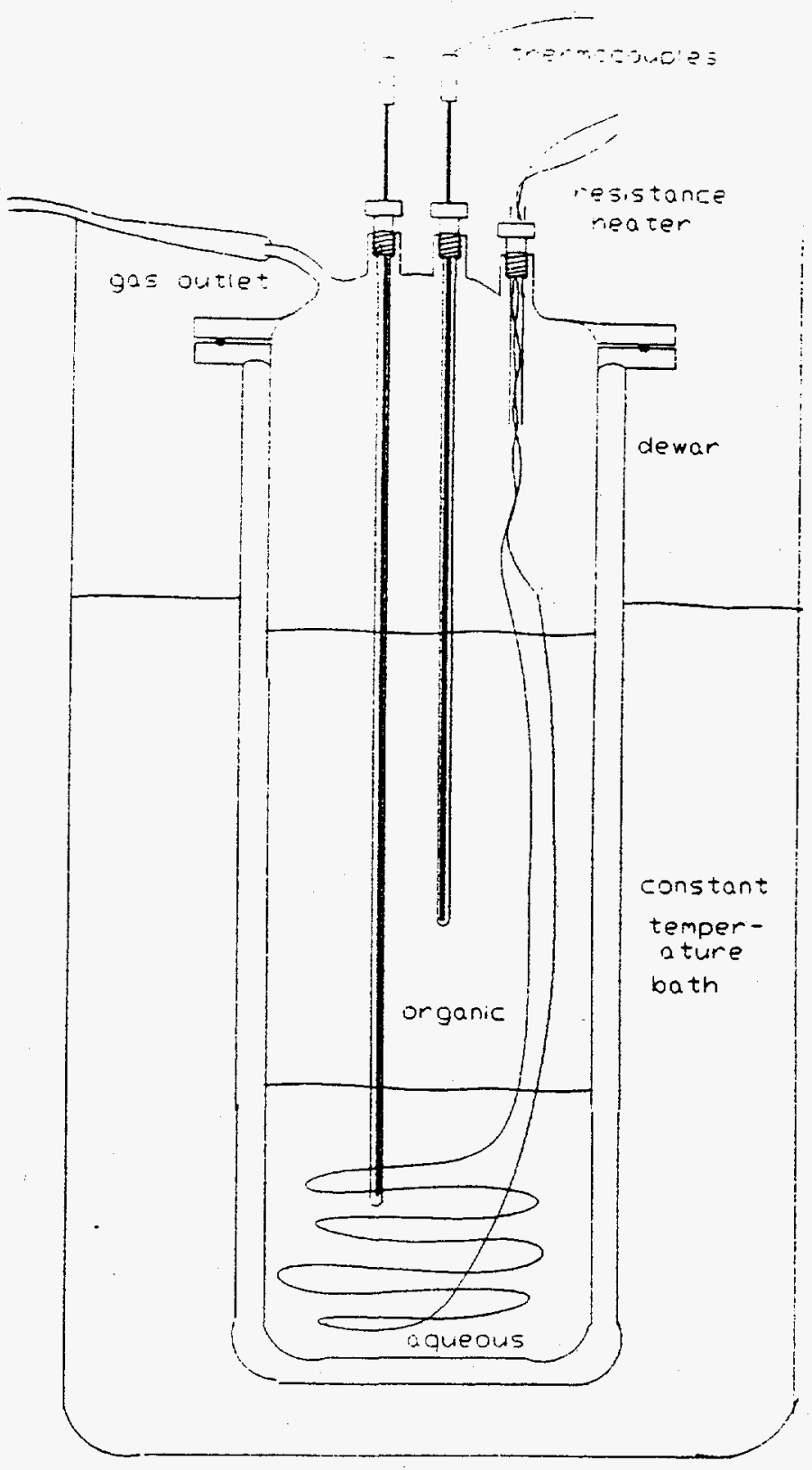

Figure 3. Heat-Balance Calorimeter. 


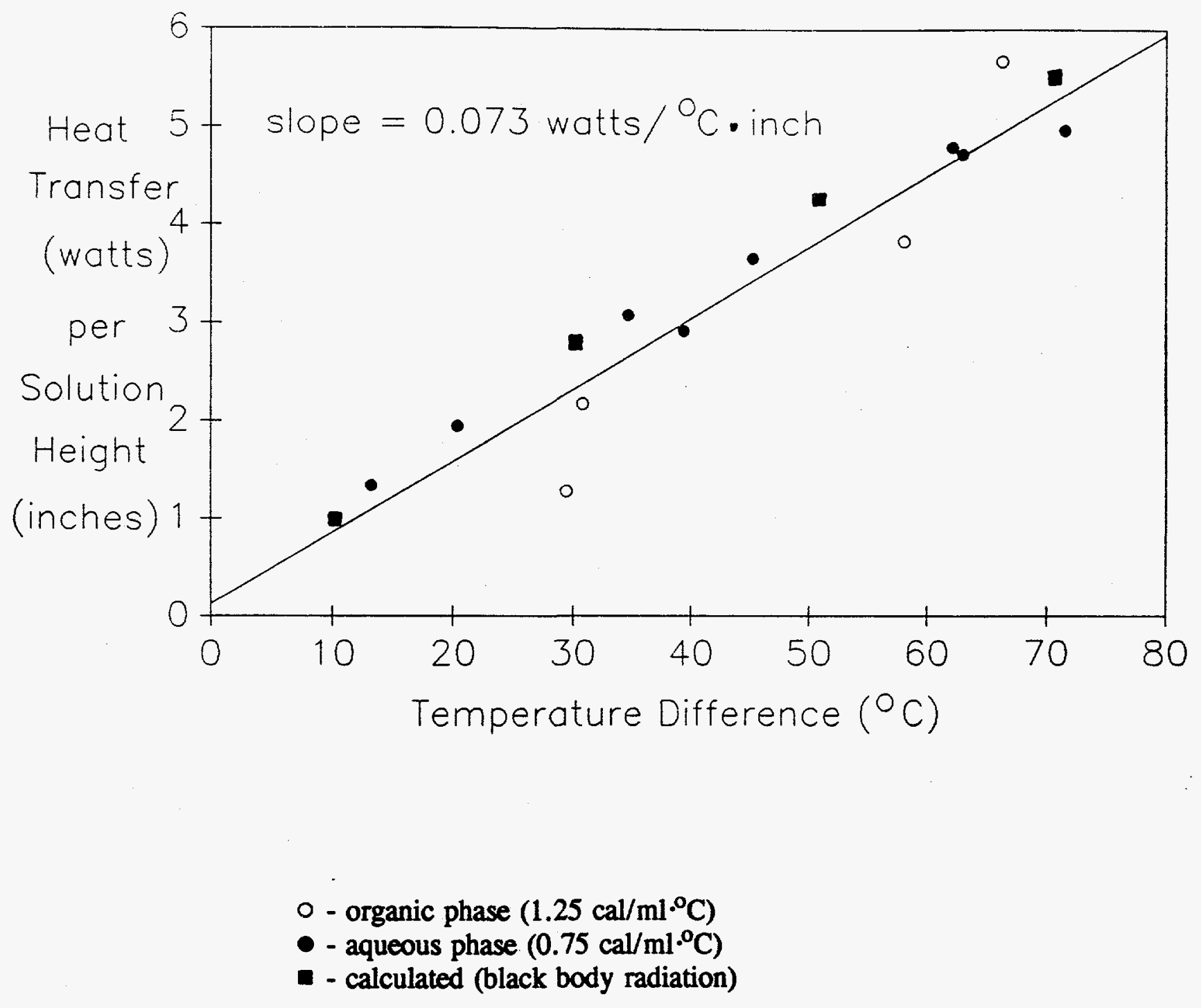

Figure 4. Heat-Balance Calorimeter Calibration. 


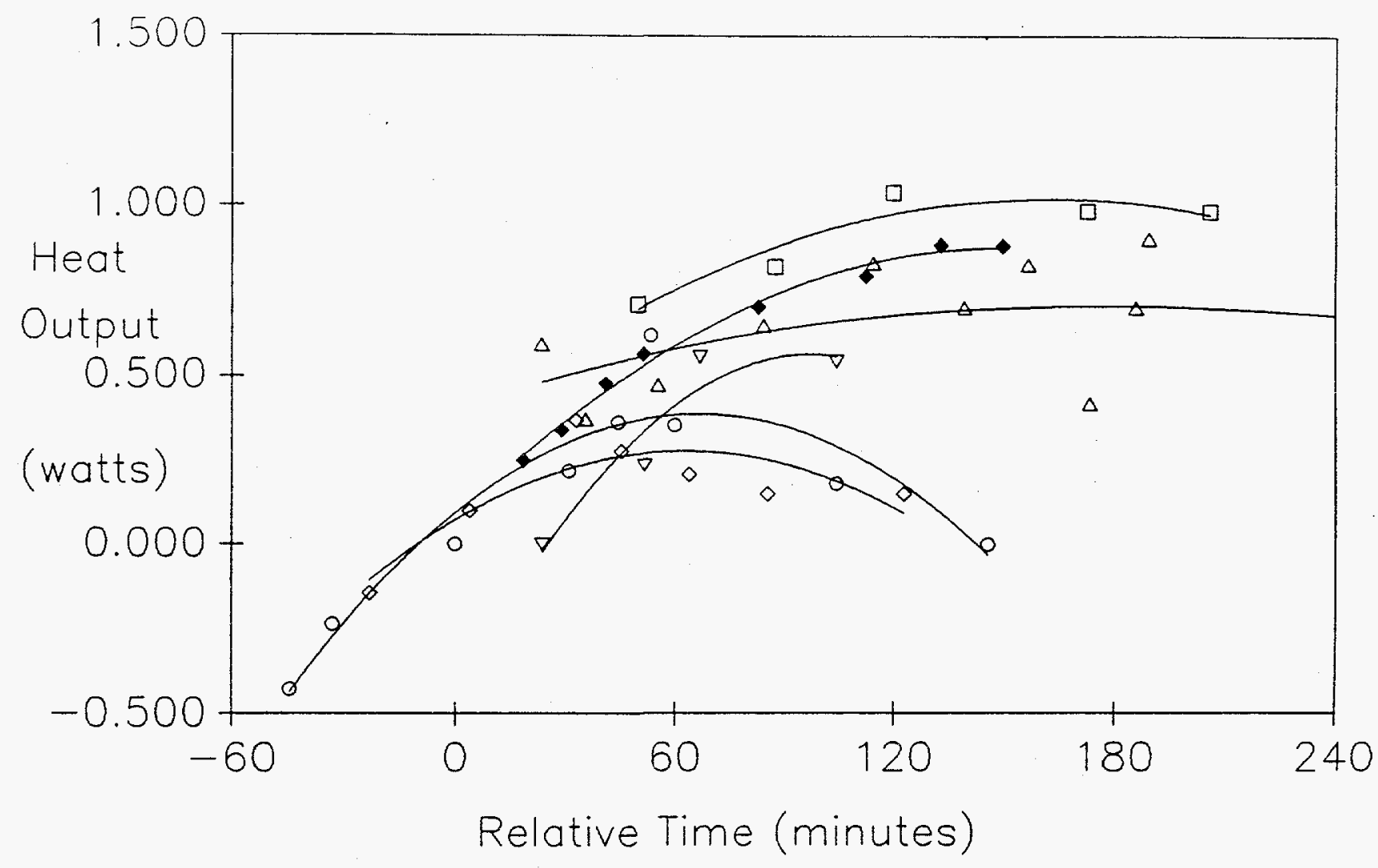

$$
\begin{gathered}
\circ, \diamond, \square, \Delta, \nabla-\text { Run\# } 2,5-8 \text { respectively } \\
\diamond-\text { Run\# } 10 \text { (purged) }
\end{gathered}
$$

Figure 5. Heat Output Versus Time, TBP (saturated with $10 \mathrm{M} \mathrm{HNO}_{3}$ ) at $110^{\circ} \mathrm{C}$. 
WSRC-TR-94-0540

$\mathrm{Pg} 32$ of 45

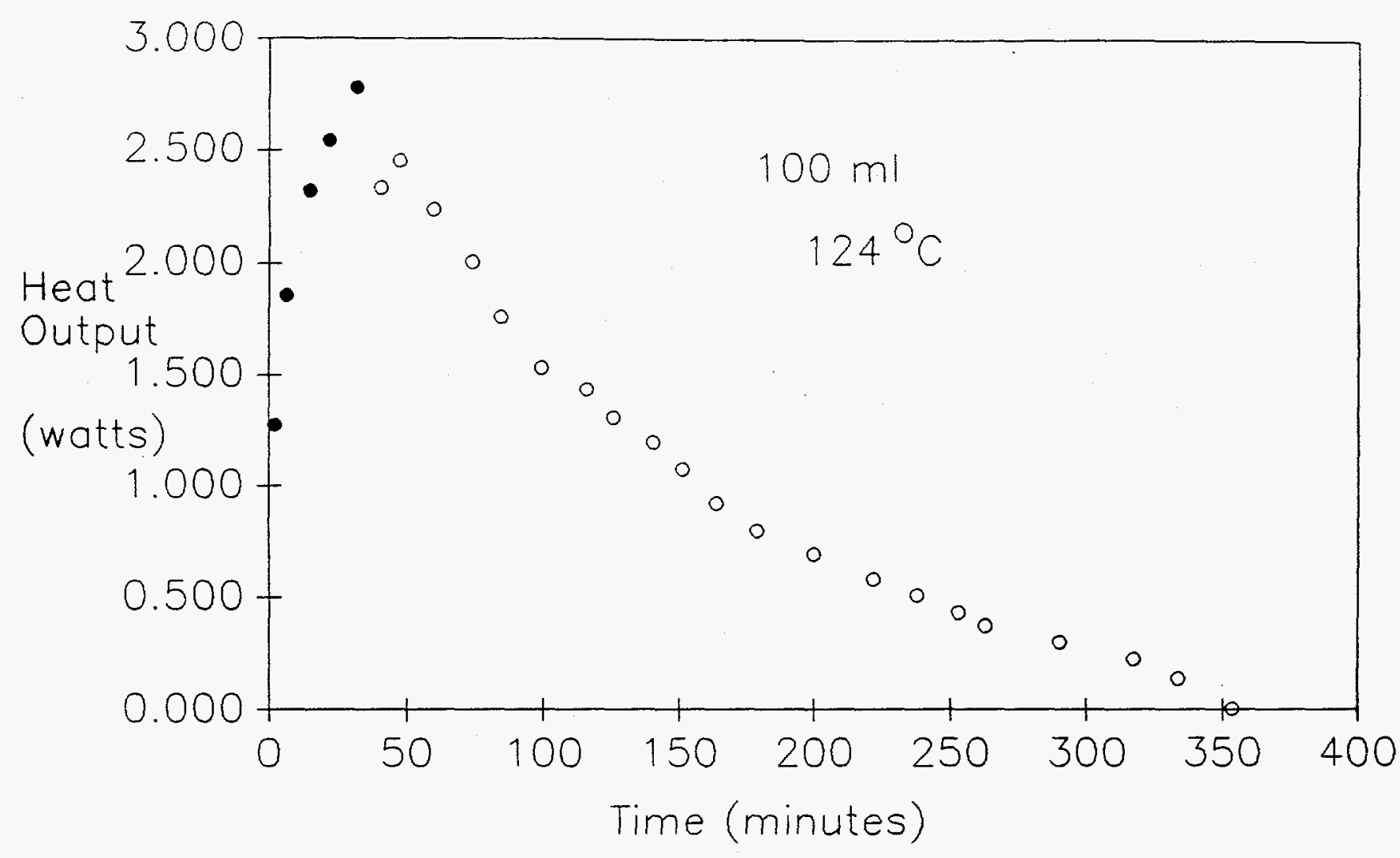

Figure 6. Heat Output Versus Time, TBP (saturated with $10 \mathrm{M} \mathrm{HNO}_{3}$ ) at $124^{\circ} \mathrm{C}$. 
WSRC-TR-94-0540

$\mathrm{Pg} 33$ of 45

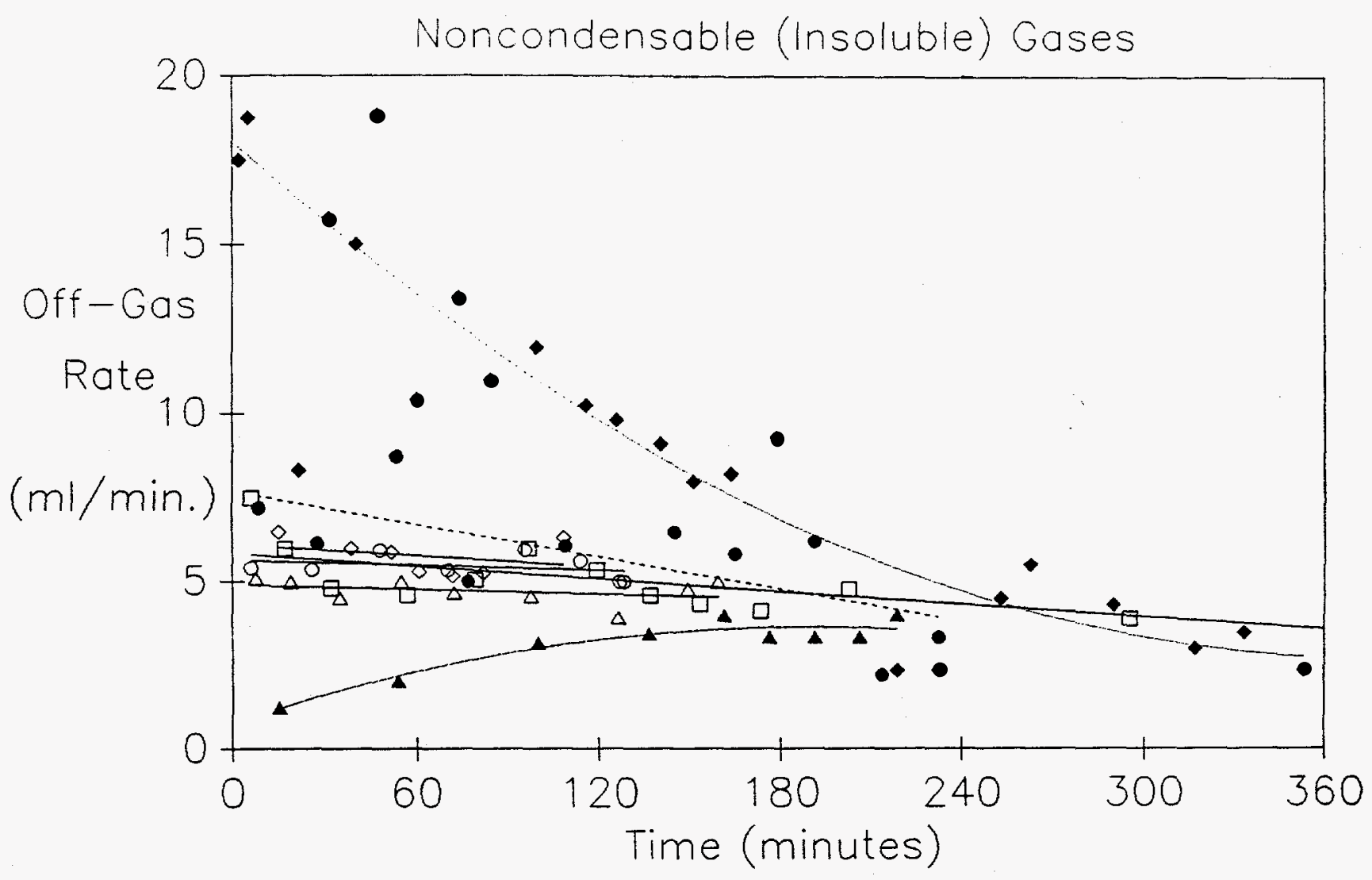

top curve - $10 \mathrm{M} \mathrm{HNO}_{3}$ saturated at $124^{\circ} \mathrm{C}$

middle dashed line - (conc.) $\mathrm{HNO}_{3}$ saturated at $110^{\circ} \mathrm{C}$ cluster of solid lines - $10 \mathrm{M} \mathrm{HNO}_{3}$ saturated at $110^{\circ} \mathrm{C}$ bottom curve - $5 \mathrm{M} \mathrm{HNO}_{3}$ saturated at $110^{\circ} \mathrm{C}$

Figure 7. Off-Gas Rate Versus Time for Single Phase Runs 
WSRC-TR-94-0540

$\mathrm{Pg} 34$ of 45

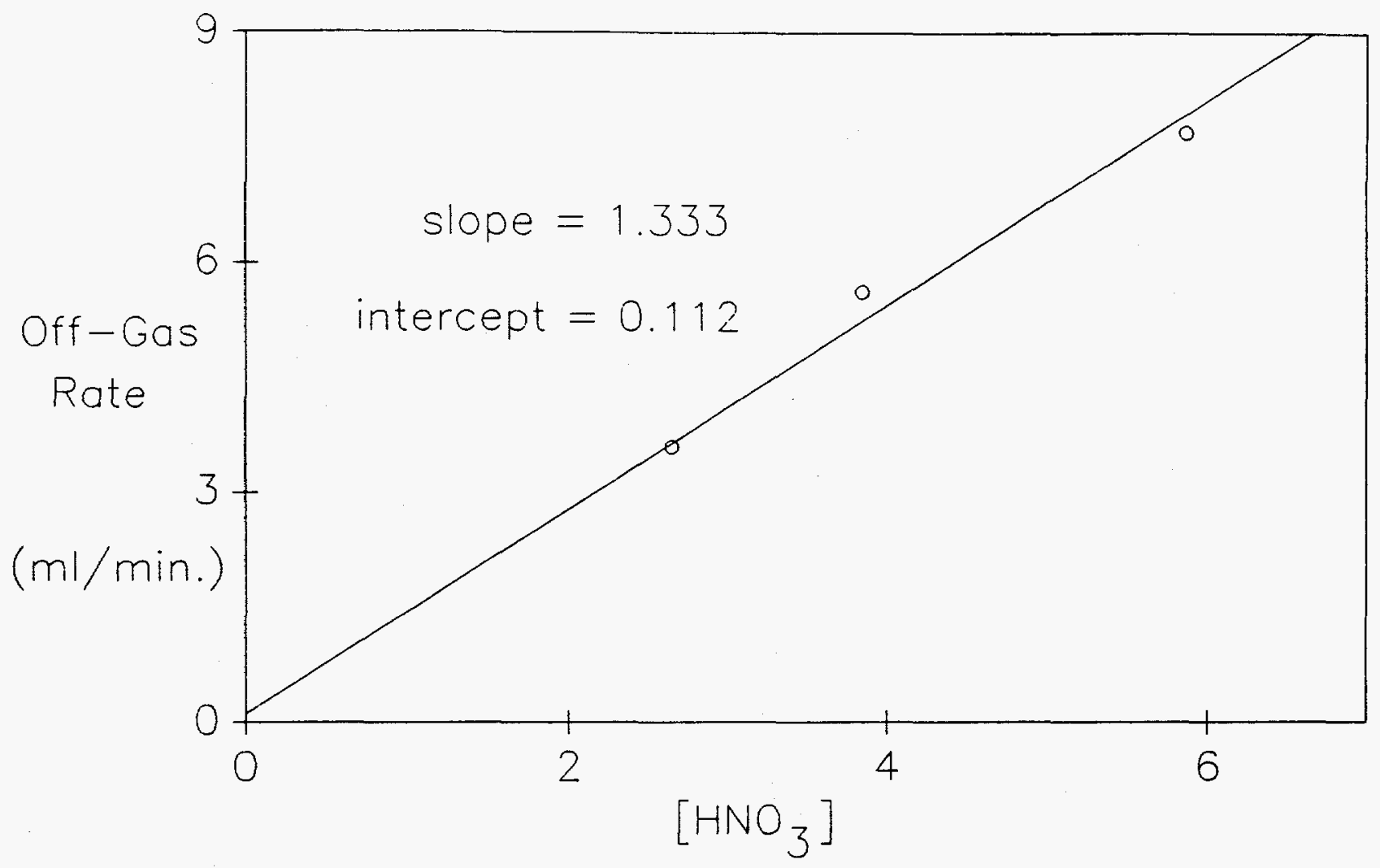

Figure 8. Oxidation Rate Dependence on $\left[\mathrm{HNO}_{3}\right]$ (organic phase). 
WSRC-TR-94-0540

$\mathrm{Pg} 35$ of 45

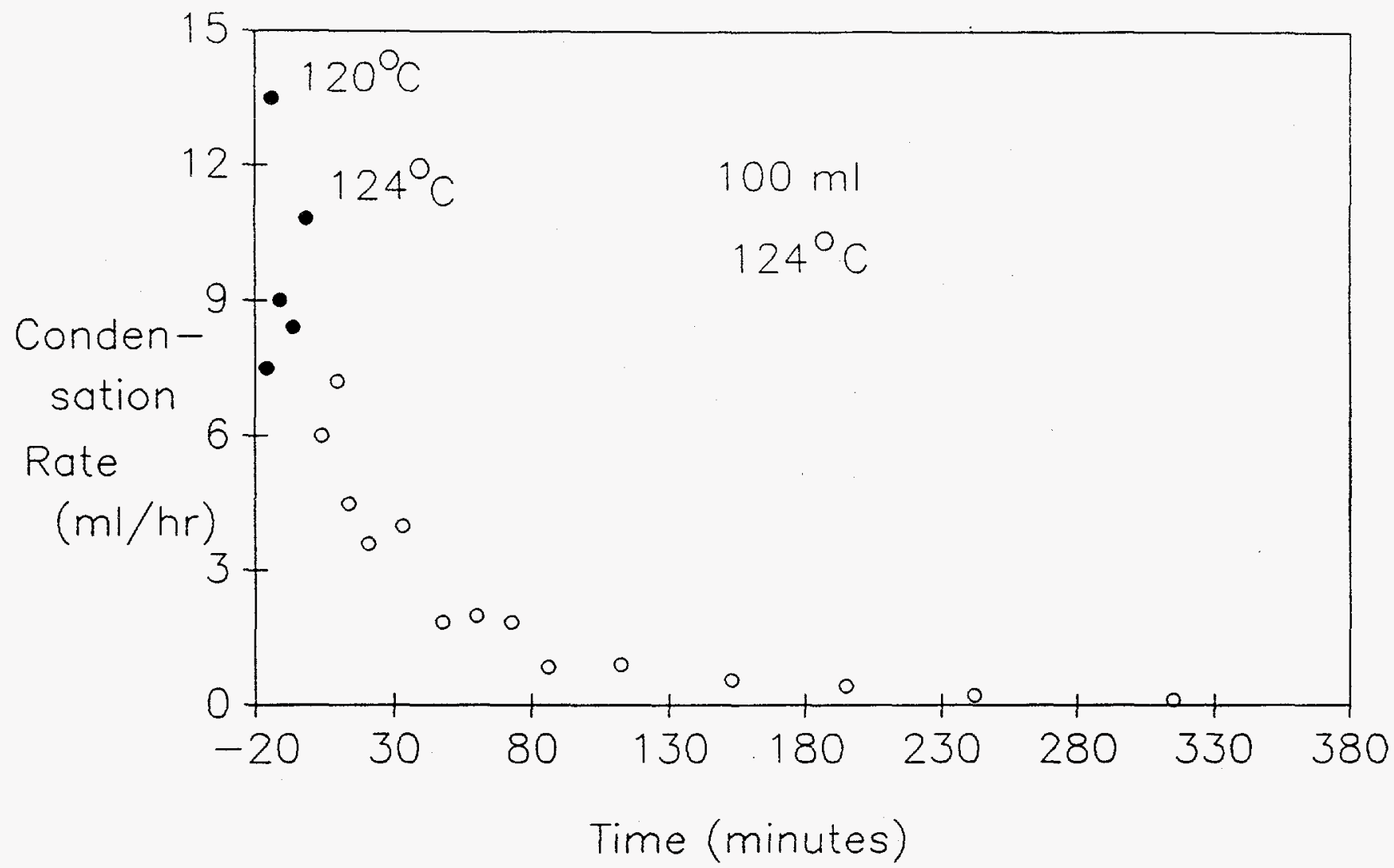

- Data taken prior to heat output measurements

0 - Data taken during heat measurements.

Figure 9. Condensation Rate Versus Time at $124^{\circ} \mathrm{C}$. 
WSRC-TR-94-0540

$\mathrm{Pg} 36$ of 45

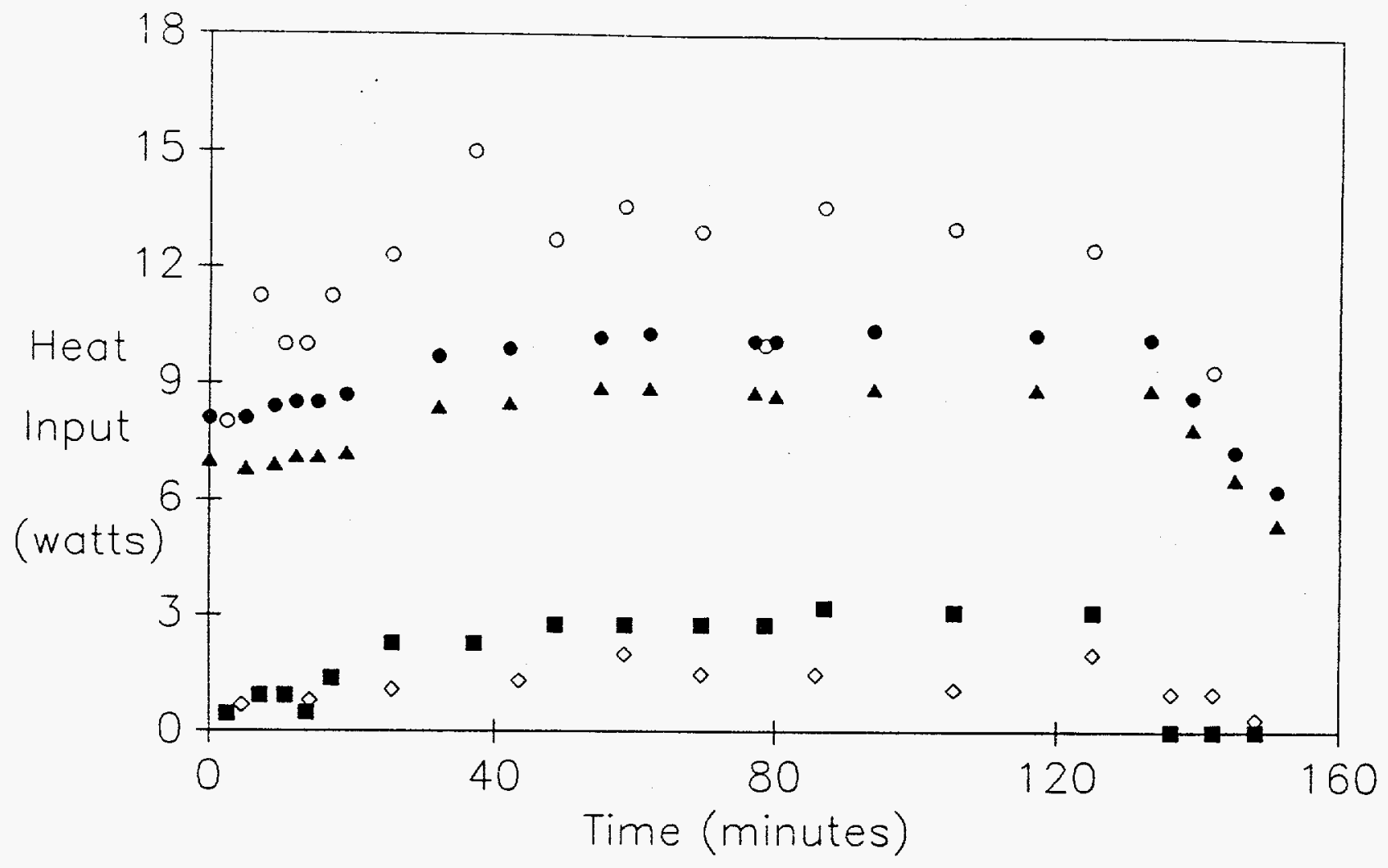

- Balancing Heat Input by Peltier (watts)

O - Off-Gas Rate (ml/minute)

$\diamond$ - Condensation Rate X 10 (ml/minute)

- Aqueous Phase Temperature, minus $100\left({ }^{\circ} \mathrm{C}\right)$

A - Organic Phase Temperature, minus $100\left({ }^{\circ} \mathrm{C}\right)$

Figure 10. Two-Phase Reaction Characteristics, $110^{\circ} \mathrm{C}$ and $1 \mathrm{OM}\left[\mathrm{HNO}_{3}\right]$ 
WSRC-TR-94-0540

$\mathrm{Pg} 37$ of 45

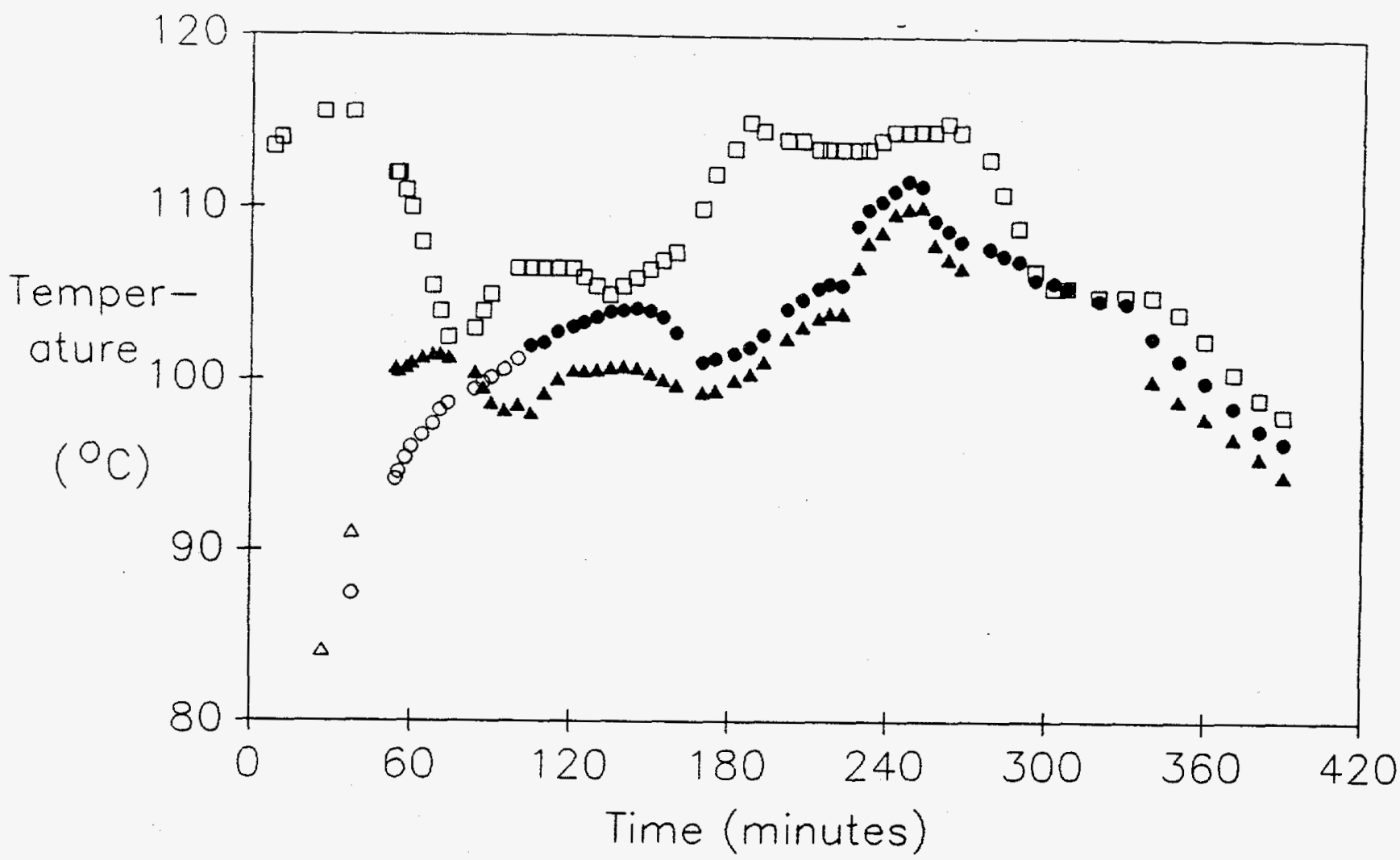

$\square$ - Bath Temperature $\left({ }^{\circ} \mathrm{C}\right)$

0 - Aqueous Phase Temperature, not oxidizing $\left({ }^{\circ} \mathrm{C}\right)$

- - Aqueous Phase Temperature, oxidizing $\left({ }^{\circ} \mathrm{C}\right)$

$\Delta$ - Organic Phase temperature, not oxidizing $\left({ }^{\circ} \mathrm{C}\right)$

- Organic Phase Temperature, oxidizing $\left({ }^{\circ} \mathrm{C}\right)$

Figure 11. Run \#15 - 4 Inches Aqueous and 5 Inches Organic Phase. 
$\mathrm{Pg} 38$ of 45

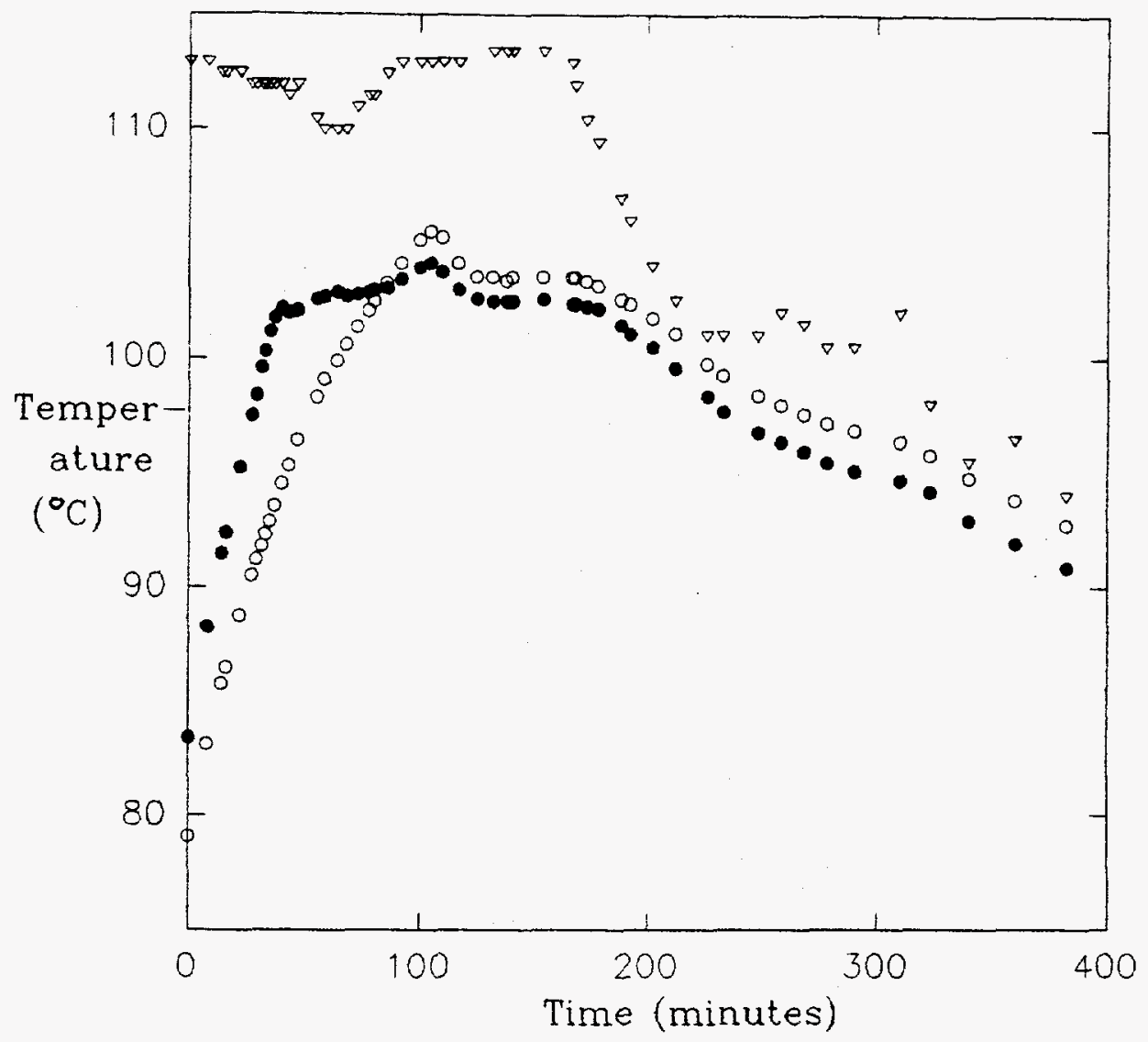

$\nabla$ - Bath Temperature $\left({ }^{\circ} \mathrm{C}\right)$

$\circ:$ Aqueous Phase Temperature $\left({ }^{\circ} \mathrm{C}\right)$

- Organic Phase Temperature $\left({ }^{\circ} \mathrm{C}\right)$

Figure 12. Run \#16 - 4 Inches Aqueous and 8 Inches Organic Phase. 


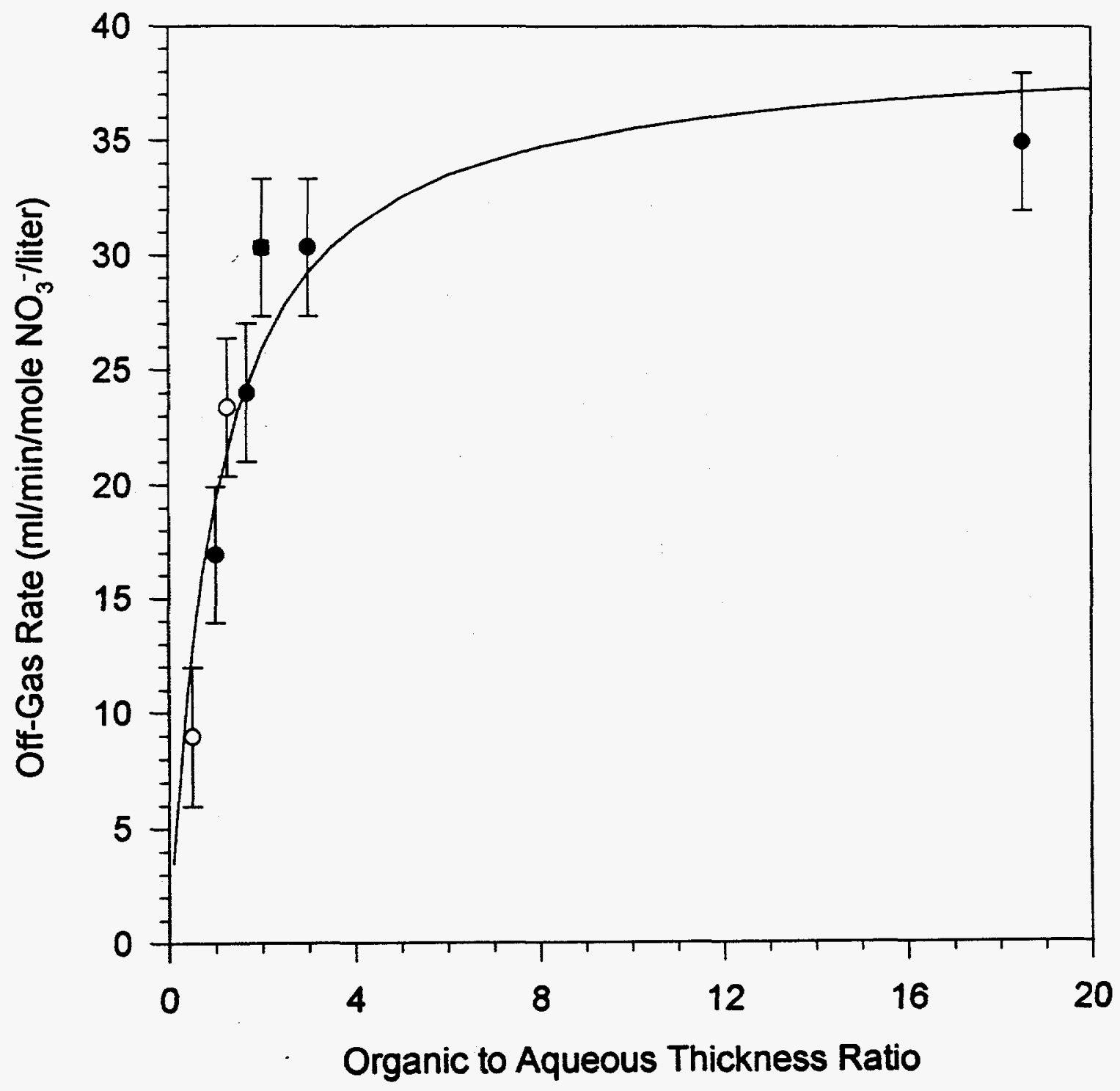

$0-6 \mathrm{M} \mathrm{HNO} \mathrm{H}_{3}$ Aqueous Phase

- $8 \mathrm{M} \mathrm{HNO}$ Aqueous Phase

- $10 \mathrm{M} \mathrm{HNO}_{3}$ Aqueous Phase

Figure 13. Organic to Aqueous Thickness Ratio Versus Total Off-Gas Rate. 
WSRC-TR-94-0540

$\mathrm{Pg} 40$ of 45

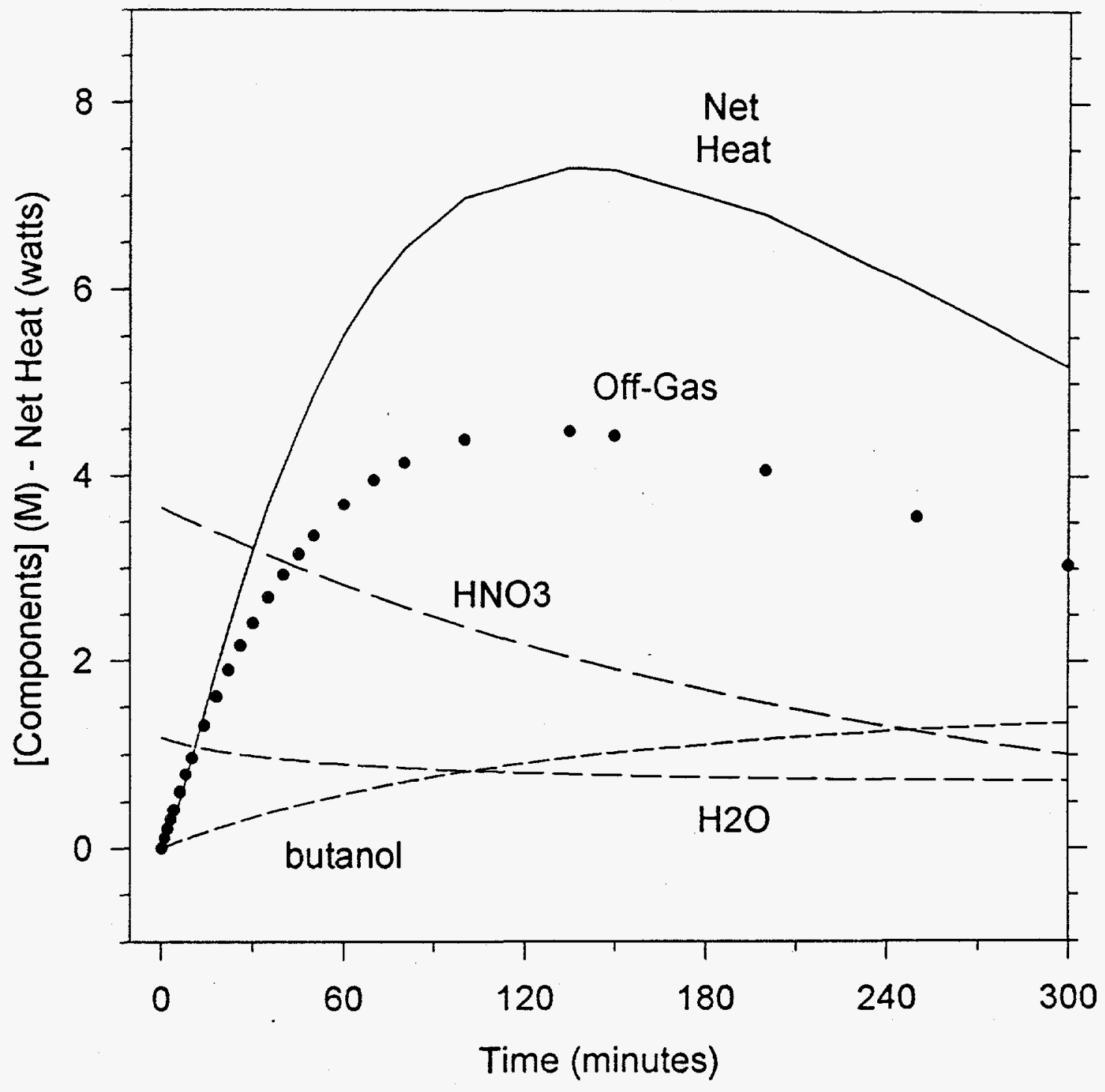

Figure 14. Effect of First Order Dependence on [Butylnitrate]. 


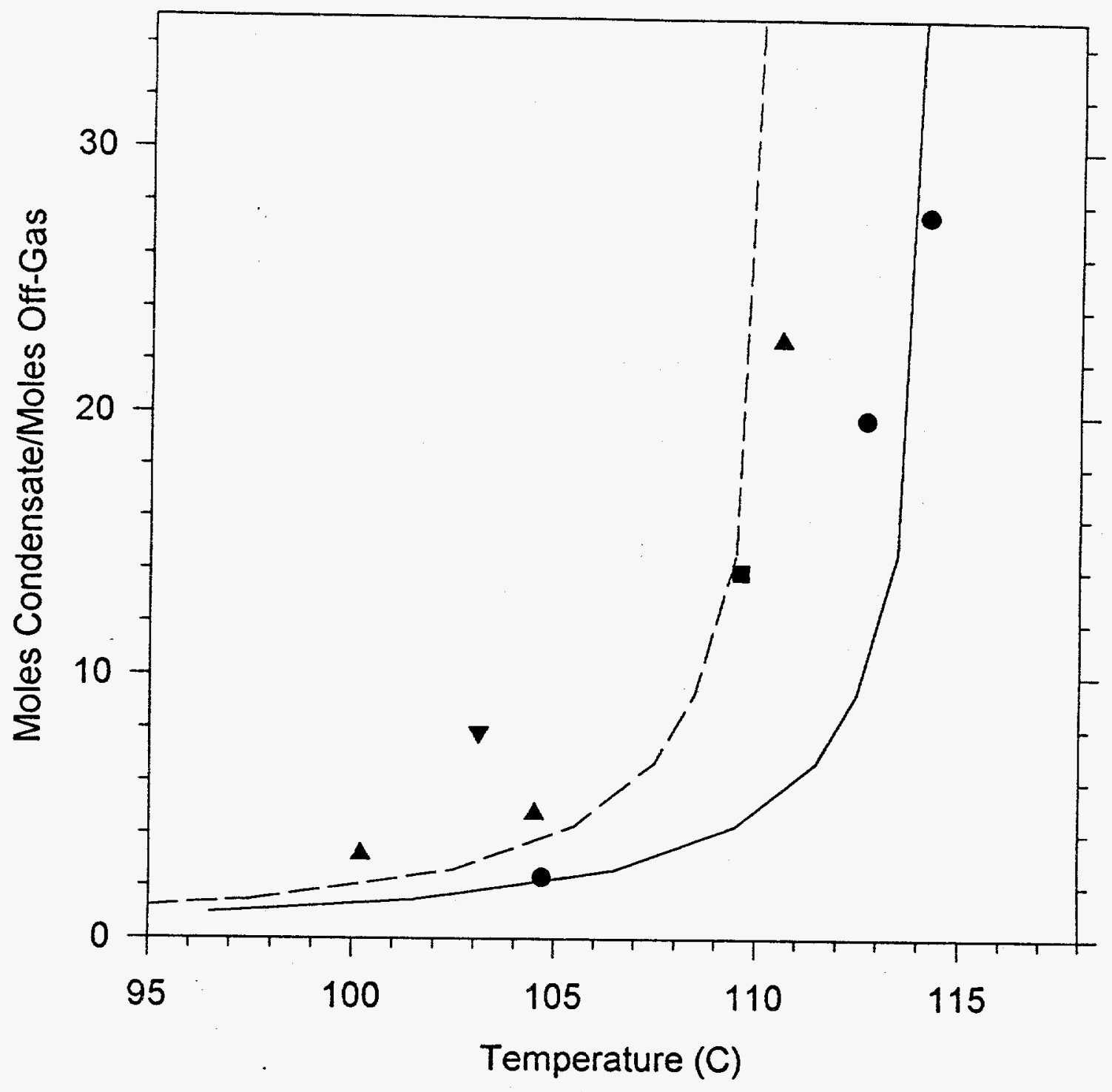

- - Run \#16,103 ${ }^{\circ} \mathrm{C}$ maximum (lowest boiling point)

$\triangle$ and $=$ - Runs \# 13 and $15,110^{\circ} \mathrm{C}$ maximum

- Run \#14, $114^{\circ} \mathrm{C}$ maximum (highest boiling point)

Figure 15. Mole Ratio Condensate to Off-Gas Versus Temperature. 
WSRC-TR-94-0540

$\mathrm{Pg} 42$ of 45

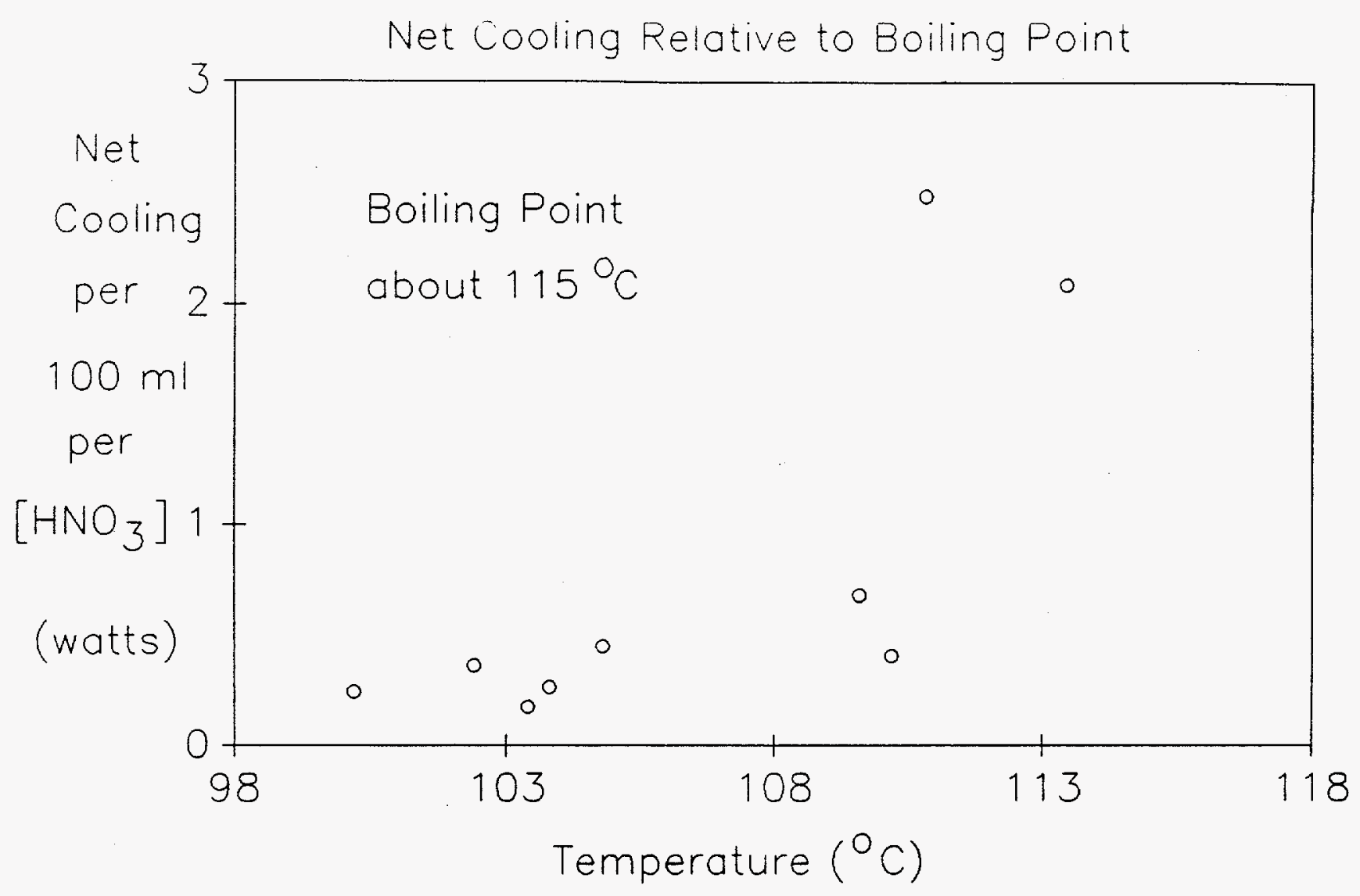

Figure 16. Net Cooling Rate Relative to Boiling Point, $\sim 114^{\circ} \mathrm{C}$. 


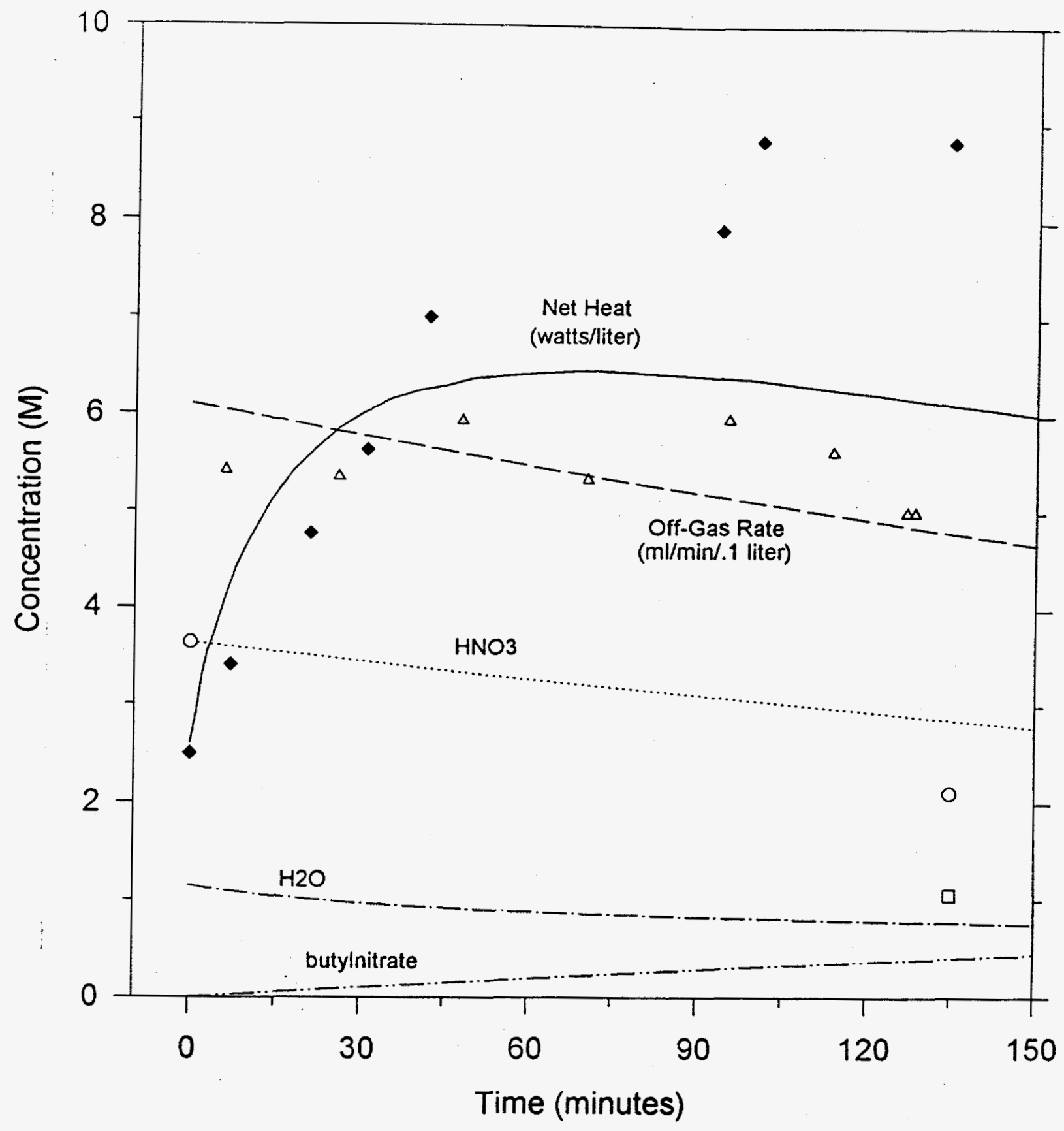
- Net Heat (watts/liter)
$\Delta$ - Off-Gas Rate (ml/min :1 liter)
$\circ-\left[\mathrm{HNO}_{3}\right](\mathrm{M})$
व - [butylnitrate] (M)

Figure 17. Model Fit to Single Layer $\left(110^{\circ} \mathrm{C}\right)$ Experimental Data. 
WSRC-TR-94-0540

$\mathrm{Pg} 44$ of 45

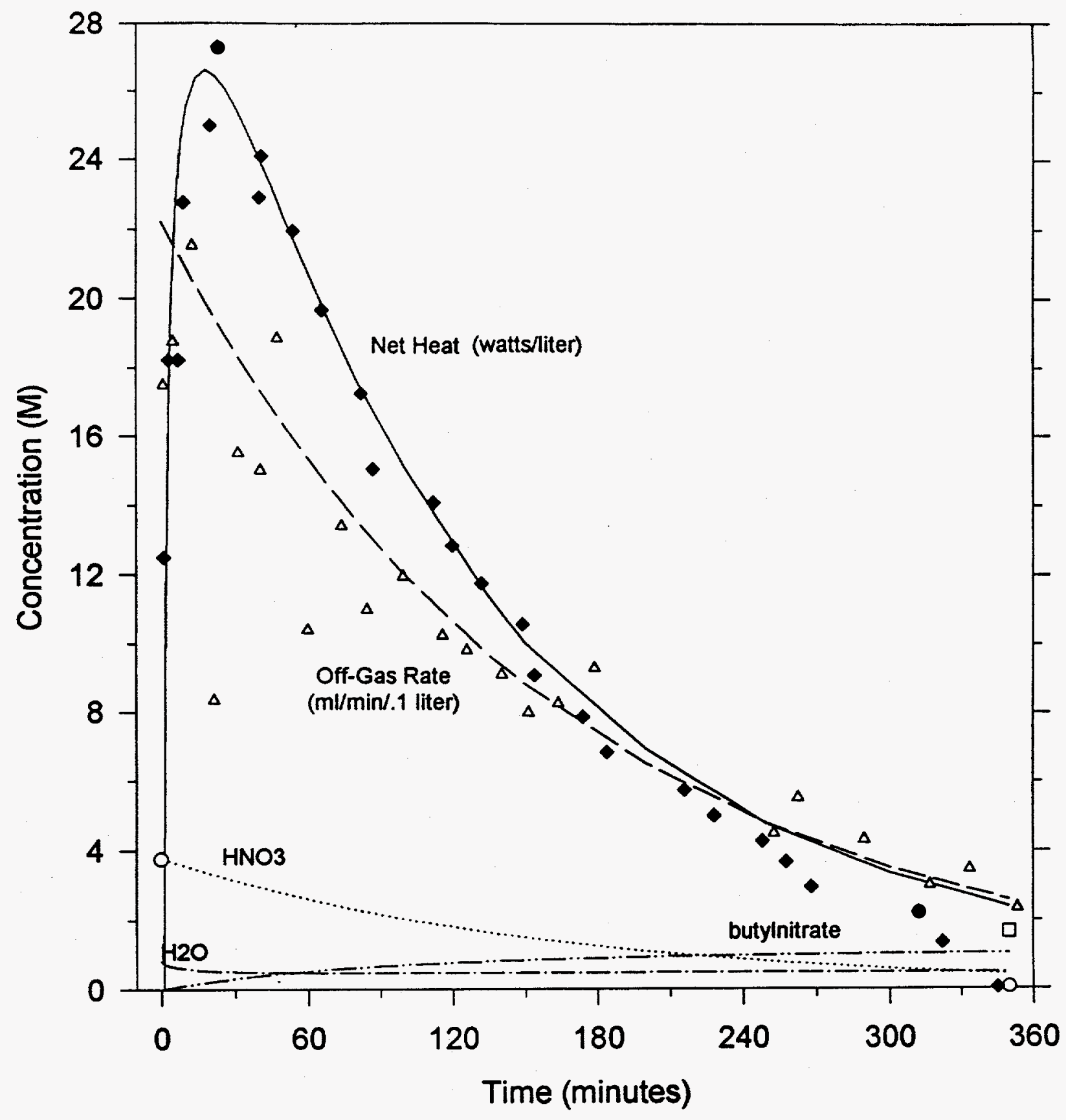

- - Net Heat (watts/liter) $\Delta$ - Off-Gas Rate (ml/min $: 1$ liter)

$\circ$ - $\left[\mathrm{HNO}_{3}\right](\mathrm{M}) \quad$ - [butylnitrate] (M)

Figure 18. Model Fit to Single Layer $\left(124^{\circ} \mathrm{C}\right)$ Experimental Data. 
WSRC-TR-94-0540

$\mathrm{Pg} 45$ of 45

DISTRIBUTION

C.R. Wolfe, 773-A

J.R. Knight, 773-A

T.G. Cambell, 992W-1

W.E Harris, Jr., 221-H

C.B. Cochran, 703-F

G.T. Geiger, $992 \mathrm{~W}-1$

W.S Cavin, 773-A
J.R. Schornhorst, 992W-1

O.M. Ebralima, 703-F

D.F. Paddleford, 992W-1

M.L. Hyder, 773-A

M.C. Thompson, 773-A

J.E. Laurinat, 773-A 